\title{
AARP
}

\section{HOW WOMEN'S FINANCIAL EXPERIENCES DURING THE PANDEMIC SHAPE FUTURE OUTLOOK}

May 2021 


\section{Table of Contents}

Introduction

Key Findings

Financial Situation Today

Retirement Savings During COVID-19

Financial Goals This Year

Expected Financial Situation Next Year

Facilitating Emergency Savings

Implications

Appendix: Respondent Profiles and Methodology

Sources

Contact
3

5

8

19

26

30

35

38

40

48

50

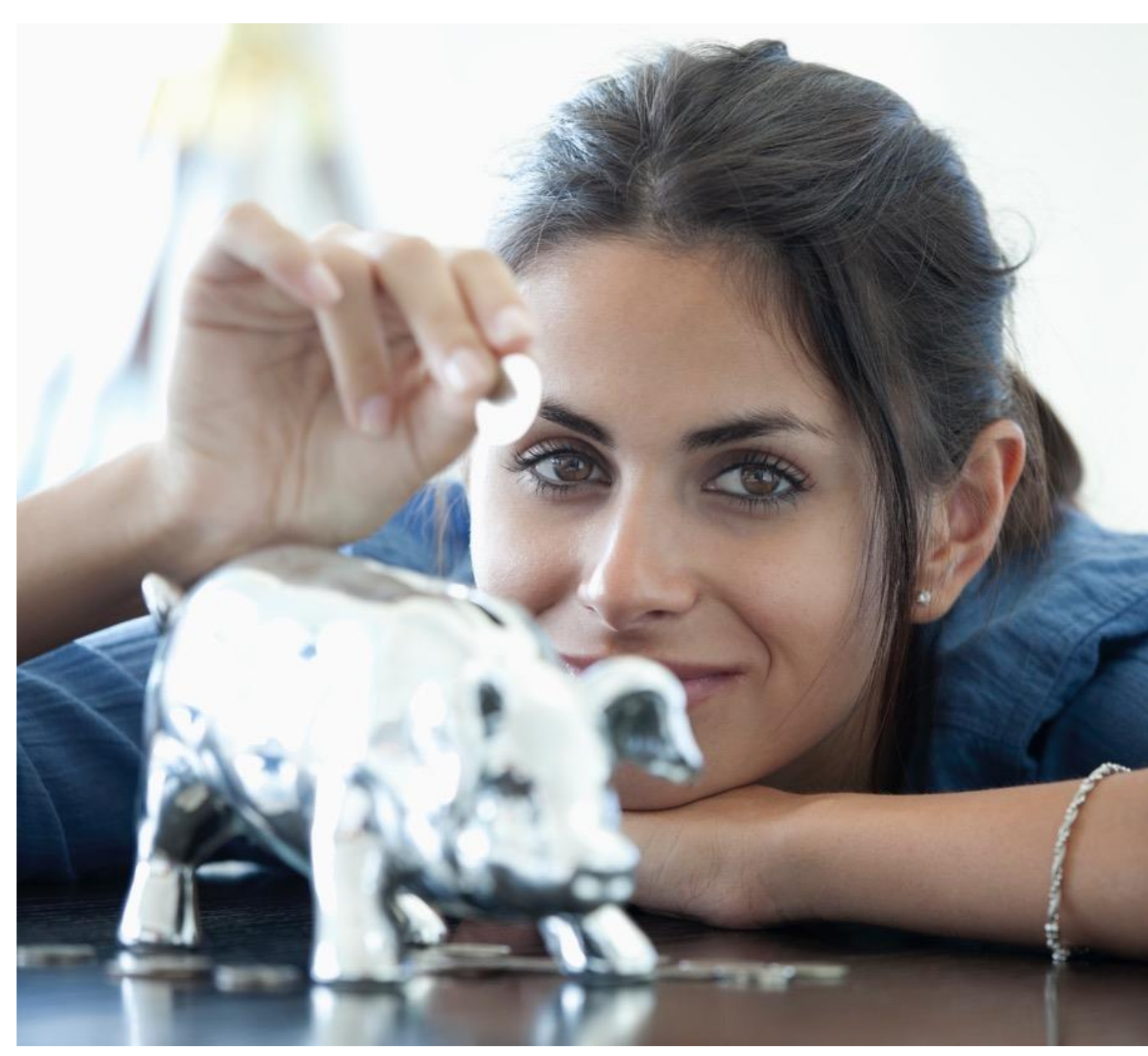




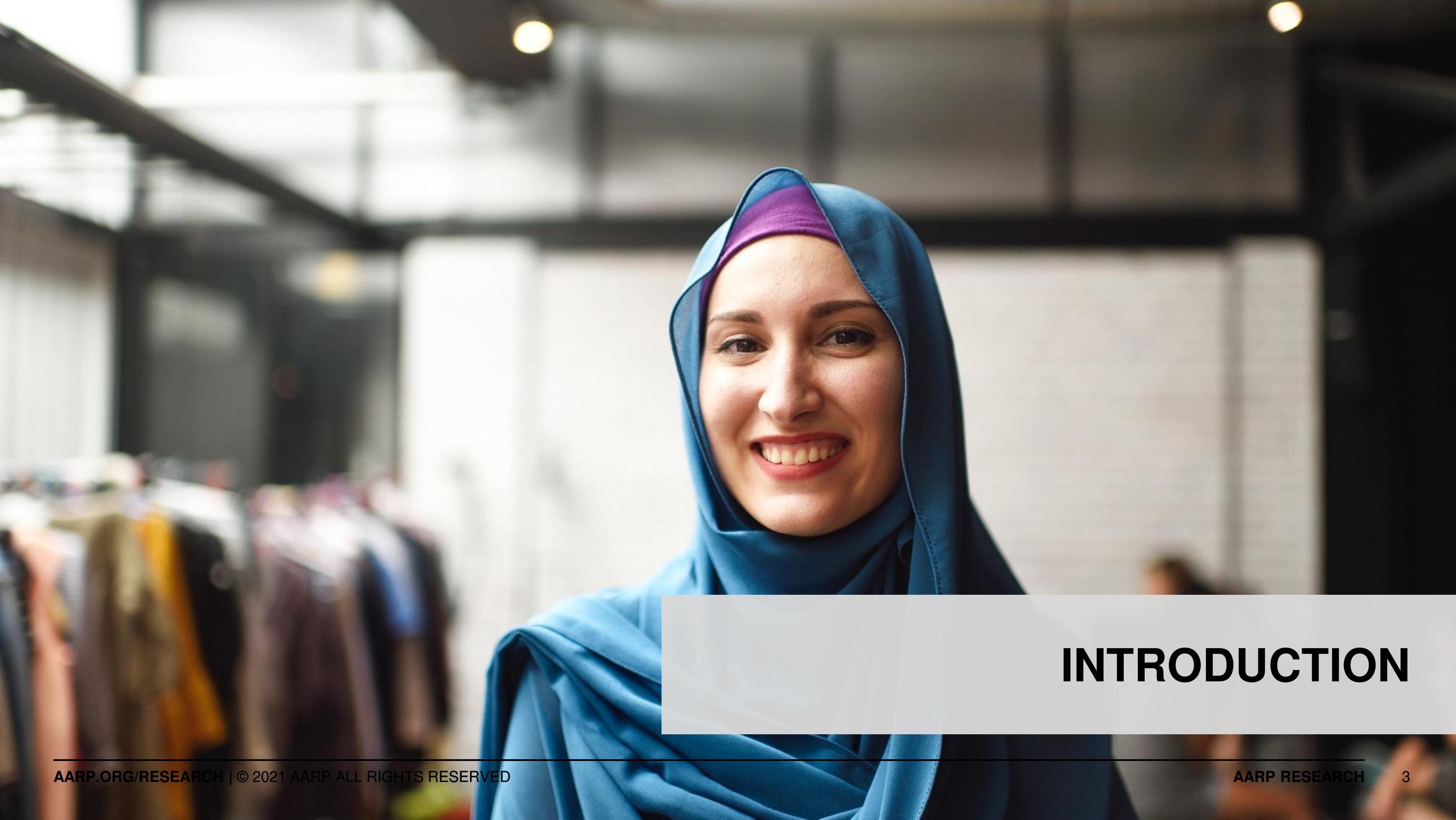




\section{Introduction}

Due to the COVID-19 pandemic, many workers lost jobs or faced reduced hours starting in early 2020 , especially those in sectors that provide in-person services. Unemployment rates rose sharply and some workers eventually stopped looking for work after many months of fruitless job searching. Older workers, women, Hispanic workers, and Black workers were especially hard hit. ${ }^{1,2,3}$ While many workers were fortunate enough to have and keep jobs that enabled them to work from home during this time, many who lost jobs endured-or are still enduring-especially long periods of unemployment that will likely have long-lasting effects on their financial security. ${ }^{4}$

This report examines the extent to which the past year has affected women ages 25-plus, including their overall finances, debt, emergency savings, and retirement savings. It also looks at how they expect their finances will change over the next 12 months and their financial goals for the next 12 months.

This detailed report on women is the second in a series of AARP reports based on a survey of adults ages 25-plus that was conducted from January 13 to February 8, 2021 to assess financial experiences during the first 12 months of the pandemic (from roughly February 2020 to February 2021). The first report uncovered stark differences in the experiences of women compared to men, including the fact that women are less likely than men to be satisfied with their financial situation, more likely than men to say that their financial situation is worse now compared to a year ago, and more likely than men to be struggling with debt. This report takes an in-depth look at the financial experiences of women, answering questions such as which subsets of women suffered the most setbacks and which subsets of women emerged from the pandemic better off.

The survey included adults who are working, looking for work, or who have worked or looked for work in the past 12 months. The survey also includes sizable samples of Hispanic workers and Black workers, who were affected disproportionately by job loss during the pandemic. * Upcoming reports in this series will focus on Hispanic workers and Black workers. **

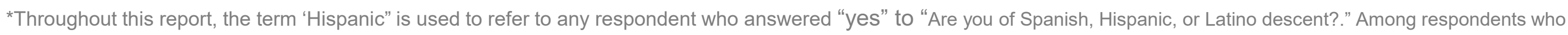

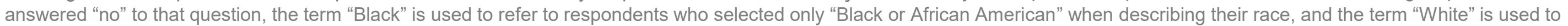
refer to respondents who selected only "White" when describing their race.

** All published reports based on this survey may be found at www.aarp.org/financialexpectations. 


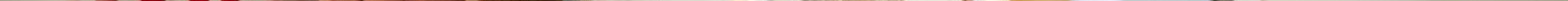




\section{Key findings}

The pandemic has been much harder financially on some women than on others. While four in $10(41 \%)$ say that their overall financial situation today is the same as it was before the pandemic, one in three $(33 \%)$ describe their situation today as worse, and one in four (26\%) describe it as better. Lower income women, Hispanic women, and those who are not working are more likely than their counterparts to view their situation as worse today than a year ago.

- Job loss and furloughs represent the key reasons that women give for a decline in their financial situation. Among those who say that their financial situation is worse today, a full half $(51 \%)$ cite job loss as a major reason.

- Among women who describe their overall financial situation as worse today, the vast majority say their ability to save for retirement $(74 \%)$ and emergencies $(75 \%)$ is worse, and more than half $(53 \%)$ say their ability to manage debt is worse.

The pressure of dealing with the here and now, such as debt payments and everyday expenses, are top barriers to saving for the future.

- Lack of money (59\%) and debt payments (46\%) are the top barriers to saving more for retirement.

- More than one in five (22\%) women prematurely dipped into their retirement savings or stopped contributing altogether since the COVID pandemic began, jeopardizing their retirement security.

Debt (52\%), expenses (48\%), and retirement savings (42\%) are the financial issues that women most commonly expect to tackle over the next 12 months.

- Of those who expect to work on their finances over the next 12 months, close to three in four (73\%) expect to reach out for financial information or help, including $28 \%$ who expect to reach out to financial professionals and $25 \%$ who expect to reach out to friends or family. 


\section{Key findings}

Most women (55\%) expect their financial situation to improve a year from now, while $33 \%$ expect it to remain the same, and just a small share $(12 \%)$ expect it to worsen. Black women, Hispanic women, younger women, and those with lower incomes are especially likely to expect their overall situation to improve.

- Among women who expect their situation to improve next year, expectations of increased income from work (39\%), a new job $(38 \%)$, and reduced debt (32\%) are the most common major reasons.

\section{Attitudes about retirement reveal a significant gap between} retirement aspirations and expected reality.

- More than eight in 10 (86\%) women say that achieving financial security in retirement is very important to them, while just one in three (33\%) think they are very likely to achieve it.

Nine in 10 women express support for the creation of workplace programs to help workers build their emergency savings, similar to workplace retirement savings programs that help workers save for retirement.

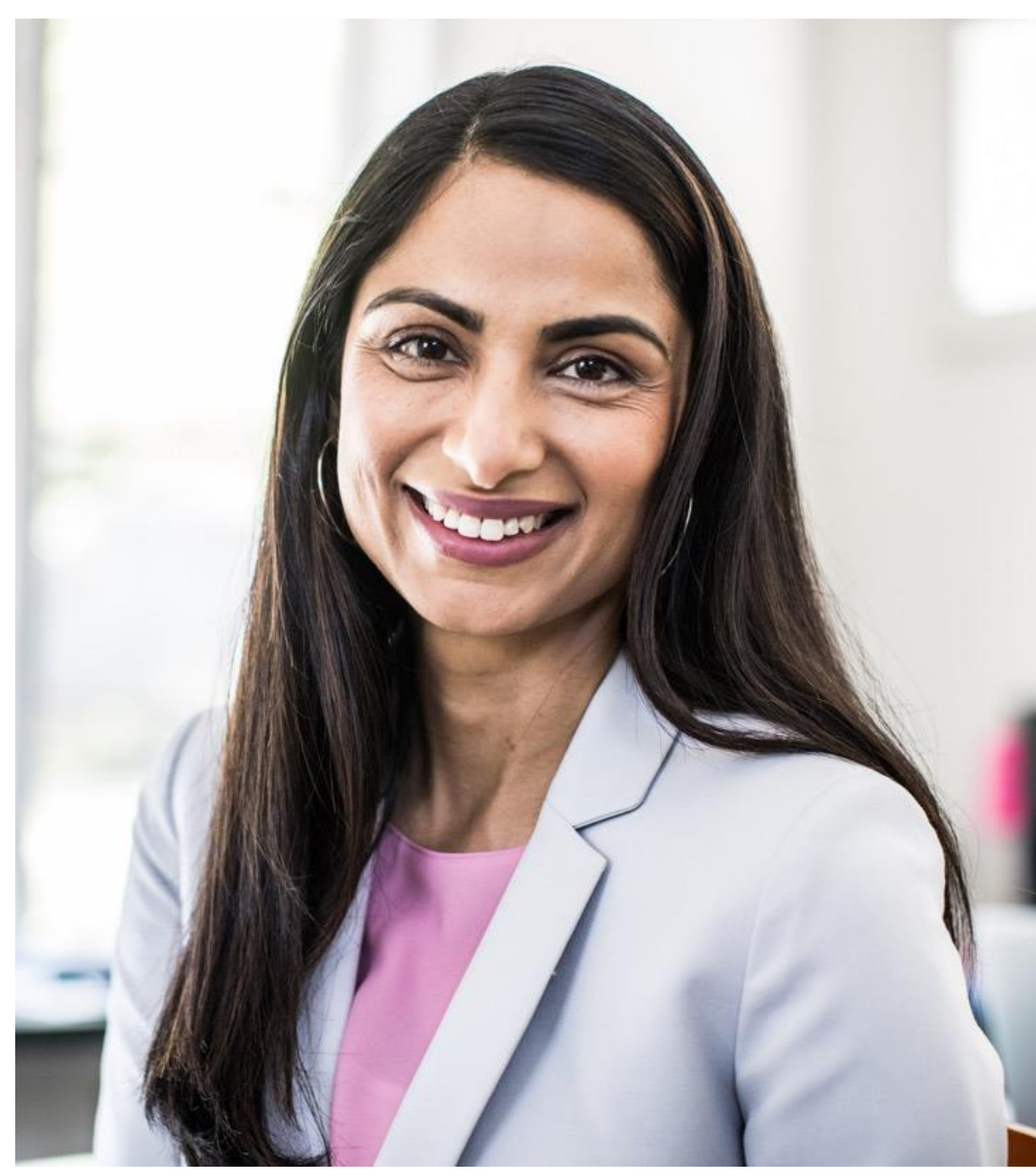

AARP RESEARCH 
FINANCIAL SITUATION TODAY 


\section{Most women ages 25-plus (58\%) are at least somewhat satisfied with their overall financial situation, but just $14 \%$ are very satisfied.}

They are less satisfied with their ability to save money (for retirement and emergencies) than with their ability to manage their debt payments. Less than half $(43 \%)$ are satisfied with their ability to save enough for retirement. Among those who are not satisfied with their overall situation, the vast majority are not satisfied with their ability to save for retirement (90\%) and emergencies (85\%).

Satisfaction with current financial situation

Among women $(n=2,887)$

- Not at all satisfied

- Not too satisfied

- Somewhat satisfied

- Very satisfied

Overall financial situation

$16 \%$

$44 \%$

$14 \%$

Ability to manage debt

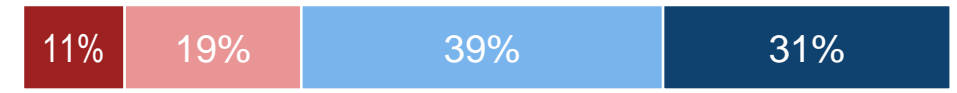

Ability to save for emergencies

$20 \%$

$34 \%$

$19 \%$

Ability to save for retirement
$27 \%$
Satisfaction with current financial situation Among women who are not satisfied $(n=1,326)$

- Not at all satisfied $\square$ Not too satisfied $\square$ Somewhat satisfied $\square$ Very satisfied

Ability to manage debt

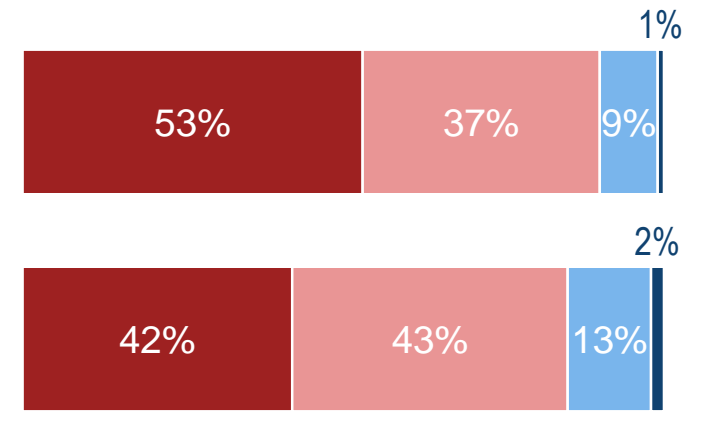

Ability to save for retirement

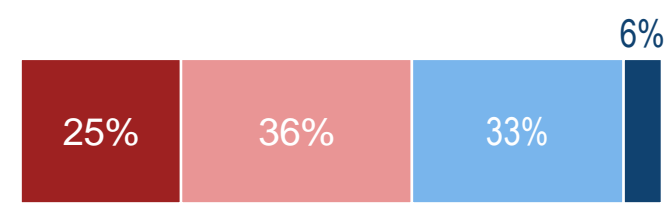




\section{Among women, satisfaction with their overall current financial situation varies by demographics, especially by income.}

Women with incomes of $\$ 75 \mathrm{~K}+$ are twice as likely to be satisfied with their financial situation as those with incomes under $\$ 40 \mathrm{~K}$ (78\% vs. 39\%). As might be expected, those who are working are more satisfied than those who are not working (most of the latter are unemployed and looking for work or on temporary layoff). White women and Hispanic women are more satisfied than Black women.
Percent somewhat or very satisfied with their overall financial situation

Among women, by age, income, race/ethnicity, employment, and marital status

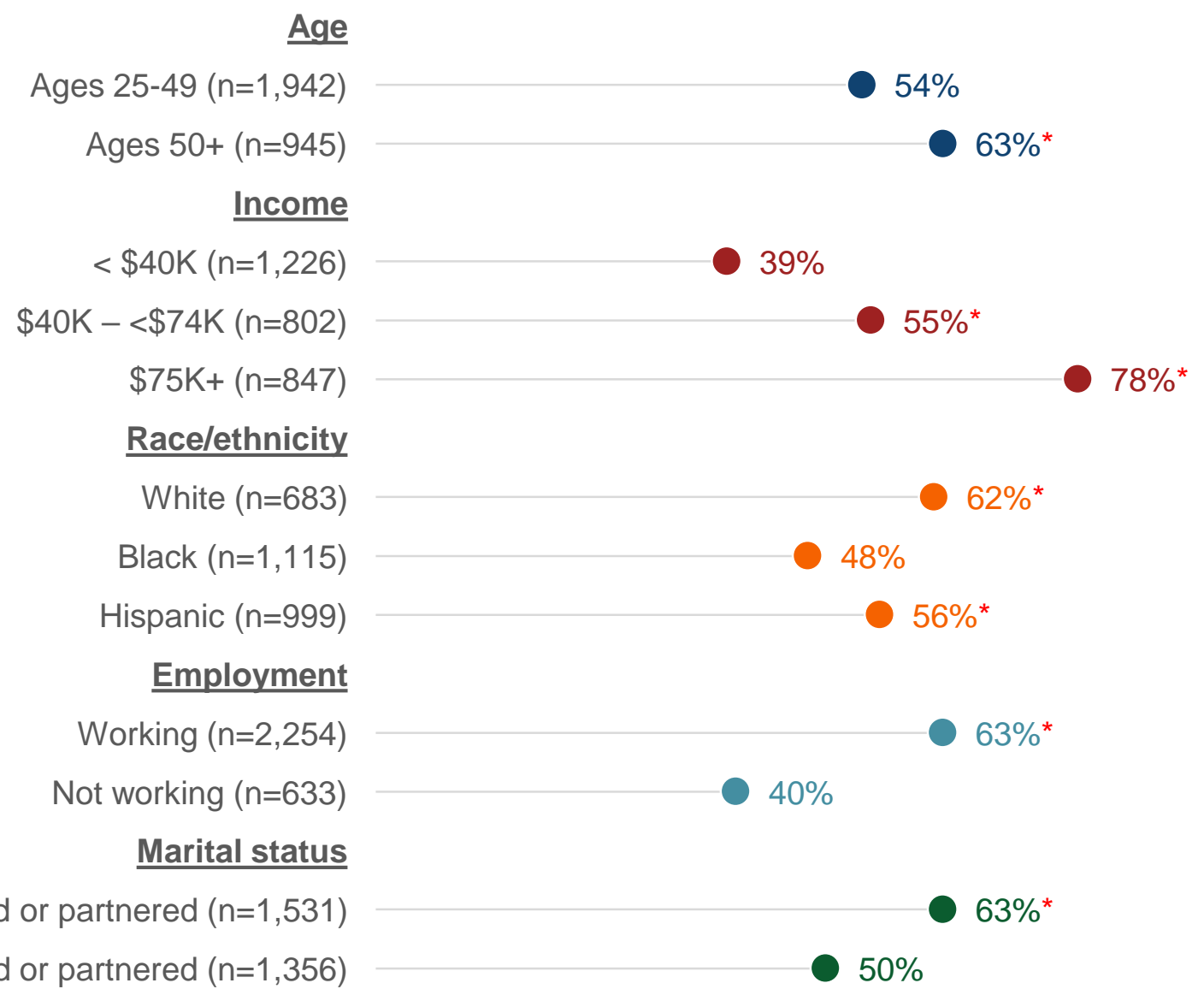




\section{Women are less likely than men to be satisfied with their financial situation, especially those with lower incomes.}

Two in three men are very or somewhat satisfied with their overall financial situation, compared to just $58 \%$ of women. The difference between men and women is particularly pronounced among lower income respondents, with just two in five (39\%) women with incomes under $\$ 40 \mathrm{~K}$ expressing satisfaction with their situation compared to nearly half $(47 \%)$ of men in this income range.

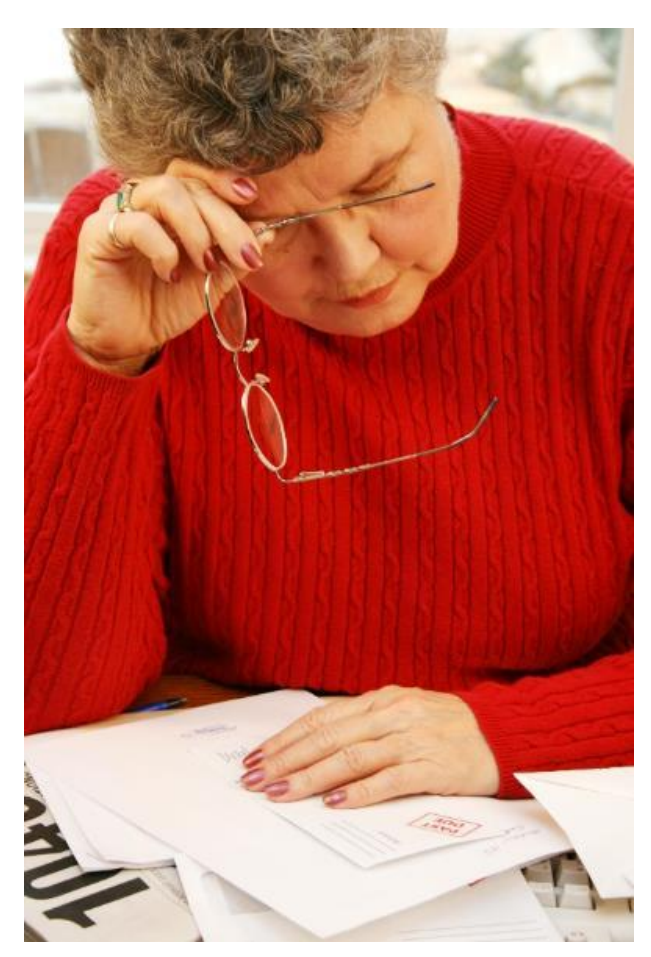

Q1d. Overall, how satisfied are you with your overall financial situation?
Percent very or somewhat satisfied with their overall financial situation

Women vs. men, all respondents and respondents earning under $\$ 40 K$

\section{All respondents}

Women $(n=2,887)$

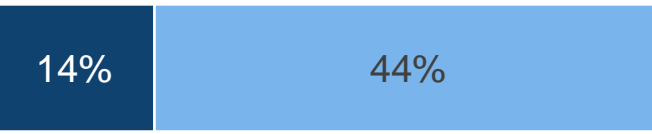

Men $(n=2,543)$

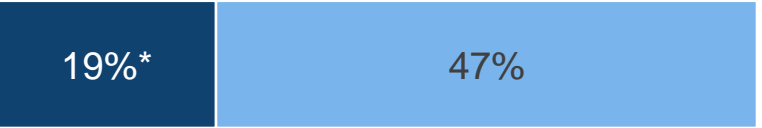

Respondents earning under $\$ 40 \mathrm{~K}$

Women $(n=1,226)$

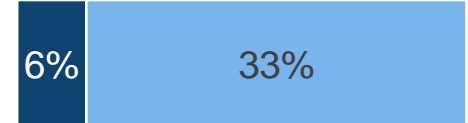

Men $(n=883)$

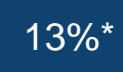

$33 \%$ 


\section{Financial experiences during the pandemic have varied. One in three women are worse off today.}

While many women (41\%) say their financial situation is the same as a year ago (before the pandemic), one in three (33\%) view it as worse and approximately one in four (26\%) view it as better. More report declines in their ability to save for emergencies and to save for retirement than in their ability to manage debt. Of those who are worse off overall, roughly three in four say their ability to save (both for emergencies and retirement) has suffered and over half say their ability to manage debt has suffered.

Financial situation today compared to a year ago

Among women $(n=2,887)$

\section{-Worse $\backsim$ Same - Better}

Overall financial situation

$$
33 \%
$$

$41 \%$

$26 \%$

Ability to manage debt

Ability to save for emergencies

Ability to save for retirement

\section{$22 \%$}

$$
33 \%
$$

$32 \%$
$23 \%$

$23 \%$

$17 \%$
Financial situation today compared to a year ago Among women whose overall situation is worse $(n=935)$

-Worse $₫$ Same -Better

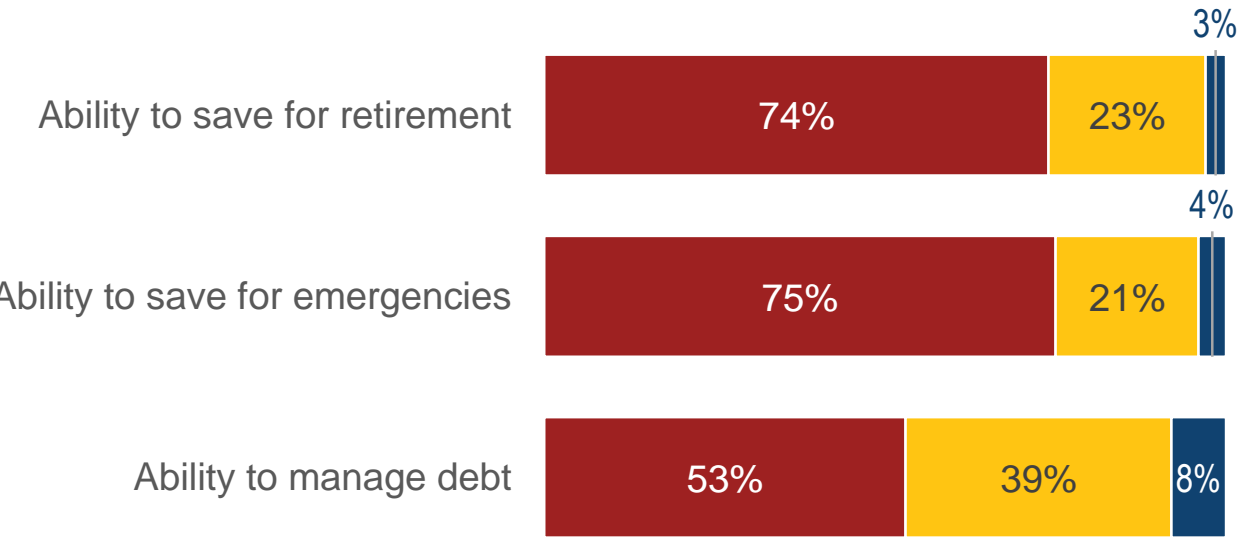




\section{Women with incomes under $\$ 40 \mathrm{~K}$, Hispanic women, and women who are not working are especially likely to say their situation is worse today.}

Women with incomes under $\$ 40 \mathrm{~K}$ are more than twice as likely as those with higher incomes to view their situation as worse ( $48 \%$ vs. $19 \%$ of women with incomes of $\$ 75 \mathrm{~K}+)$. Four in $10(40 \%)$ Hispanic women view their current financial situation as worse, compared to roughly three in 10 Black women and White women. Women who are not working are more than twice as likely as those who are working to describe their situation as worse (57\% vs. $26 \%)$.
Change in overall financial situation compared to a year ago Among women, by age, income, race/ethnicity, employment, and marital status

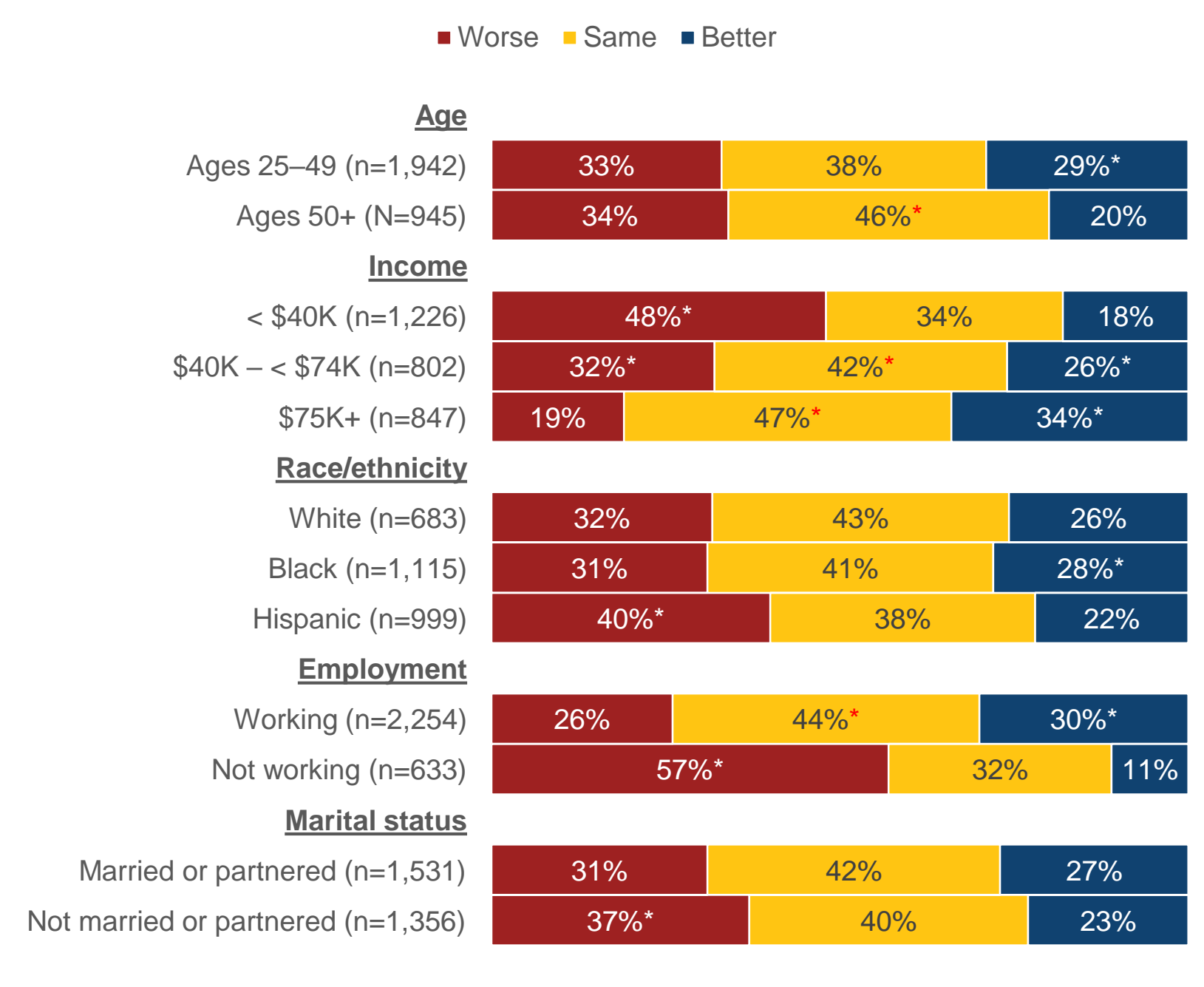




\section{Women are more likely than men to say that their situation is worse today than a year ago.}

While nearly one in three women say that they are worse off than a year ago, just $27 \%$ of men do. The difference between women and men is particularly large among those with low incomes as nearly half $(48 \%)$ of women with incomes under $\$ 40 \mathrm{~K}$ say their situation is worse than a year ago, compared to $36 \%$ of men with incomes under $\$ 40 \mathrm{~K}$.

Financial situation today compared to a year ago

Women vs. men

- Worse $\backsim$ Same -Better

Women $(n=2,887)$

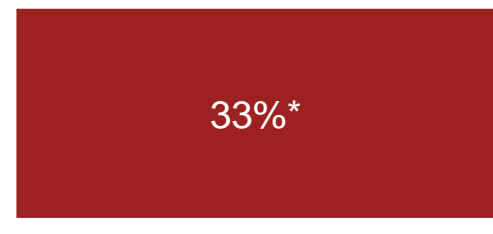

$41 \%$

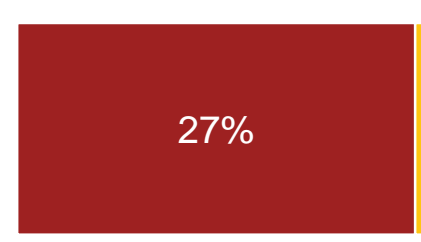

$44 \%$

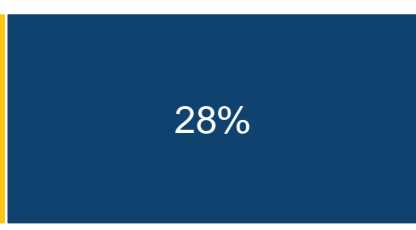

$\%$ Worse Off - Under \$40K:

$48 \%{ }^{*}$ of women with incomes under $\$ 40 \mathrm{~K}$

$36 \%$ of men with incomes under $\$ 40 \mathrm{~K}$ 


\section{Women cite job loss, furloughs, expenses, and debt as the most common reasons their situation is worse than a year ago.}

Among the $33 \%$ of women who say their financial situation today is worse than a year ago, $51 \%$ claim that job loss (their own or a household member's) is a "major reason." When forced to name the one "main" reason that their situation is worse, three in ten cite job loss.

Those ages 25-49 are more likely than those ages $50+$ to cite rising debt as a "major" reason ( $49 \%$ vs. $36 \%)$. Those with lower incomes are more likely to identify job loss $(54 \%<\$ 75 \mathrm{~K}$ vs. $41 \% \$ 75 \mathrm{~K}+)$, and higher debt $(47 \%<\$ 75 \mathrm{~K}$ vs. $31 \% \$ 75 \mathrm{~K}+)$. Hispanic women are also especially likely to cite job loss as a "major" reason (63\% of Hispanic women vs. $51 \%$ of Black women and $45 \%$ of White women).

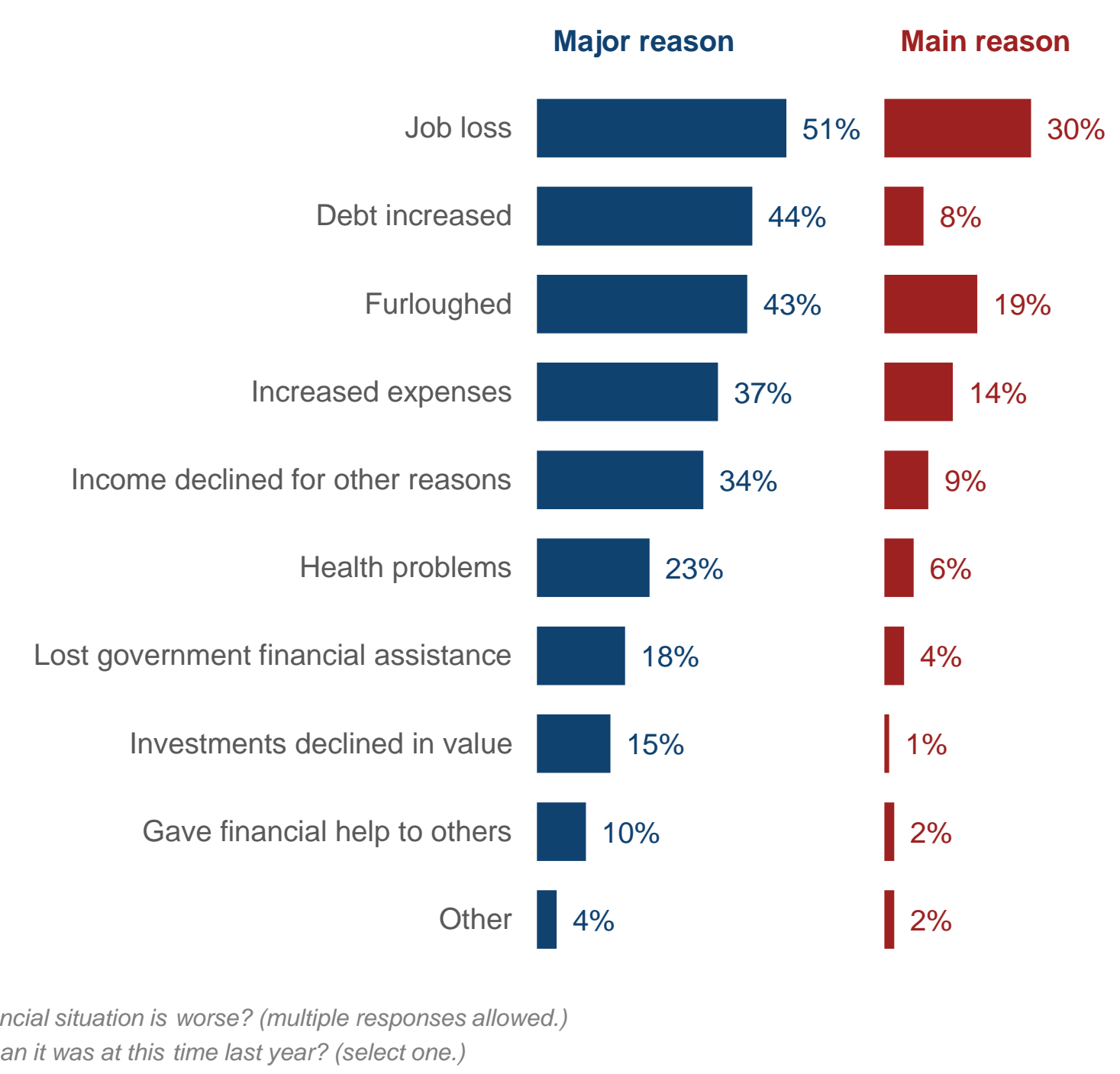

Q3. Please indicate whether each of the following is a major, minor, or not a reason that your current financial situation is worse? (multiple responses allowed.) Q4. Which of the following best describes the main reason that your current financial situation is worse than it was at this time last year? (select one.) 


\section{Women are more likely than men to cite debt as a reason for the decline in their financial situation.}

Of women who say that their financial situation today is worse than a year ago, $44 \%$ claim that increased debt is a major reason for the decline in their finances, compared to just $31 \%$ of men who say that their situation is worse.

"Debt increased" makes financial situation worse than a year ago

Women vs. men, among those whose financial situation is worse
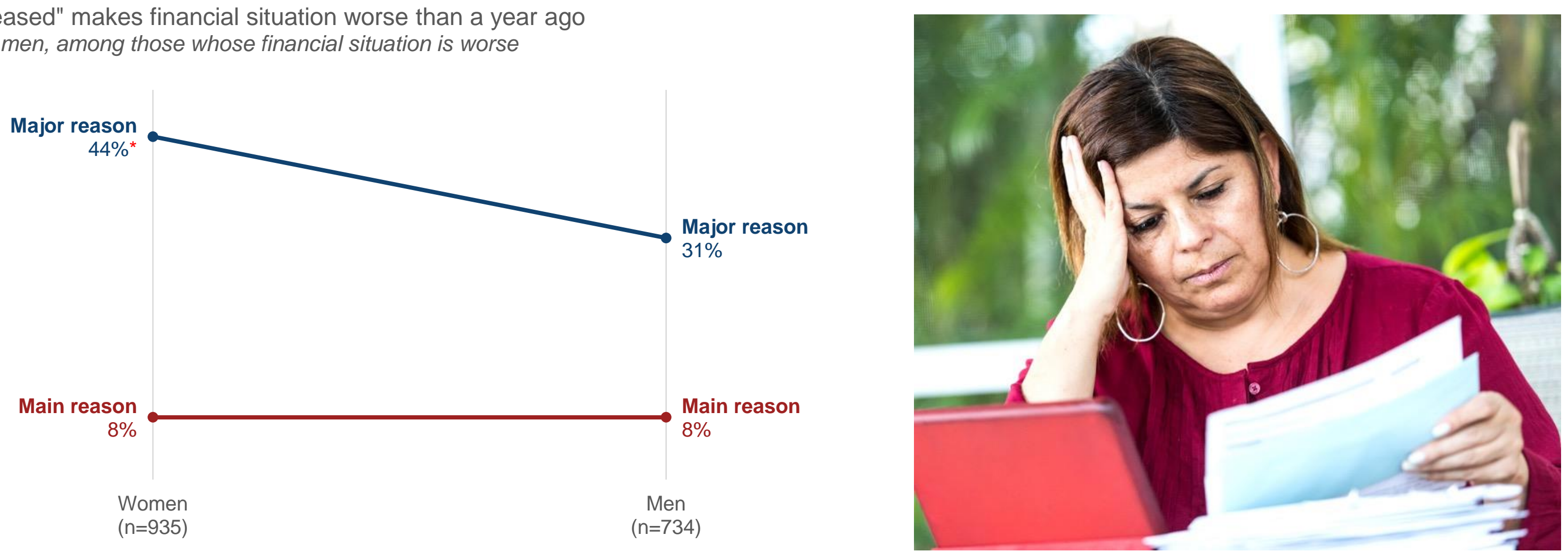

Q3. Please indicate whether each of the following is a major, minor, or not a reason that your current financial situation is worse? (multiple responses allowed.) 


\section{Increased income, a new job, and reduced debt are the most common reasons women give for feeling better about their situation today than a year ago.}

Among the $26 \%$ of women who say that their financial situation is better than a year ago, over one in three (36\%) say that increased income from work is a major reason, and more than one in five $(21 \%)$ name this as the main reason. Women ages 25-49 are more likely than those ages 50-plus to cite a new job as a major reason (34\% vs. $21 \%$ ). Hispanic women are also especially likely to cite a new job as a major reason $(39 \%$ of Hispanic women, vs. $28 \%$ of Black women and $27 \%$ of White women).
Q5. Please indicate whether each of the following is a major, minor, or not a reason that your current financial situation is better? (multiple responses allowed)

Q6. Which of the following best describes the main reason that your current financial situation is better than it was at this time
Reasons your financial situation is better than a year ago Among women whose financial situation is better $(n=785)$

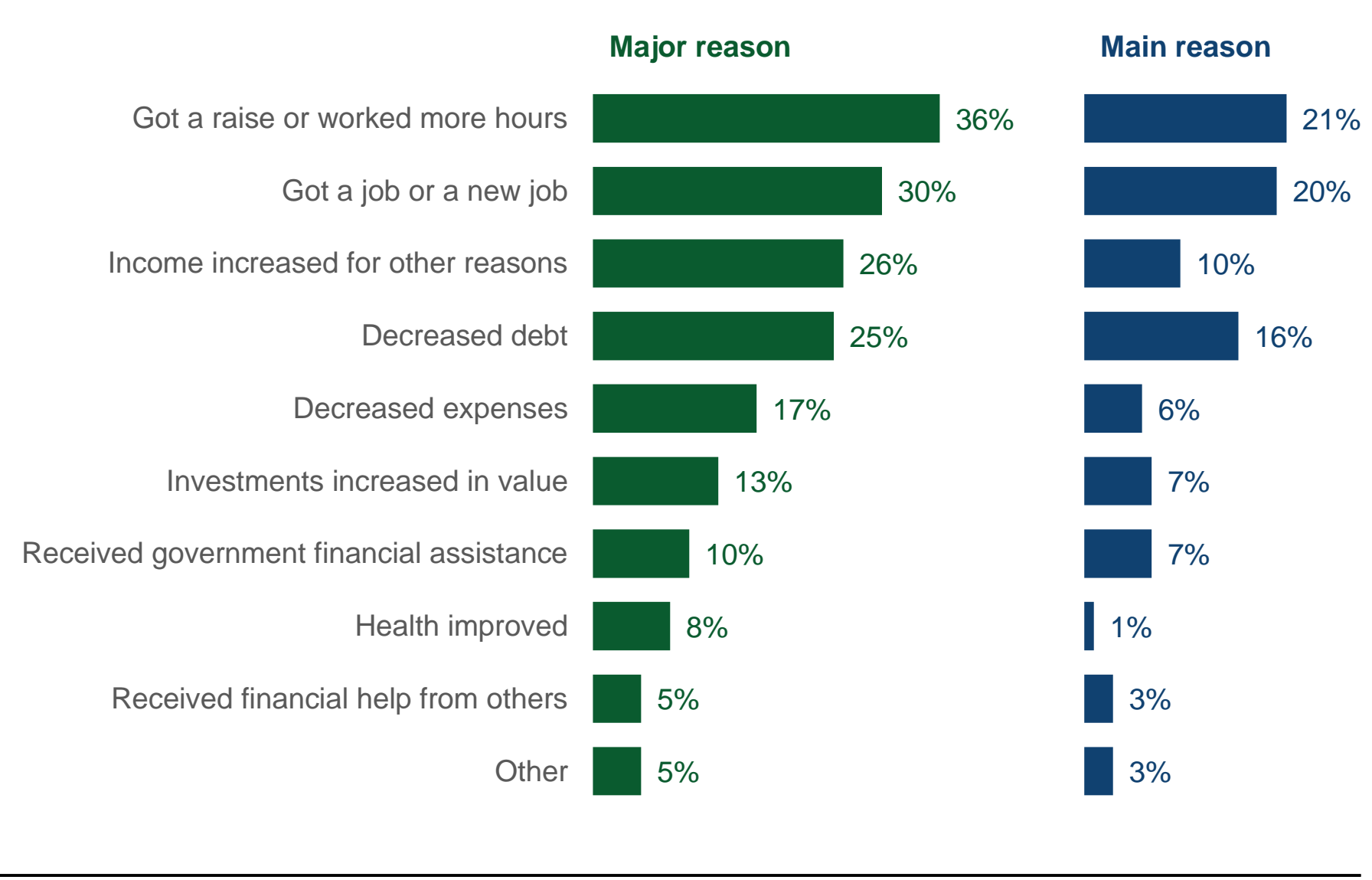

AARP RESEARCH 


\section{The vast majority of women (93\%) have not lost money due to fraud in the past year, but many of those who did felt a major impact on their finances.}

Black women (14\%) and Hispanic women (12\%) are more likely than White women (4\%) to report having lost money due to fraud over the past 12 months, as are women ages 25-49 (8\%) compared to those 50-plus (5\%). Among women who lost money, $38 \%$ say that this had a major impact on their finances, with Hispanic women especially likely to suffer a major impact (59\% of Hispanic women who lost money, and $47 \%$ of Black women who lost money).

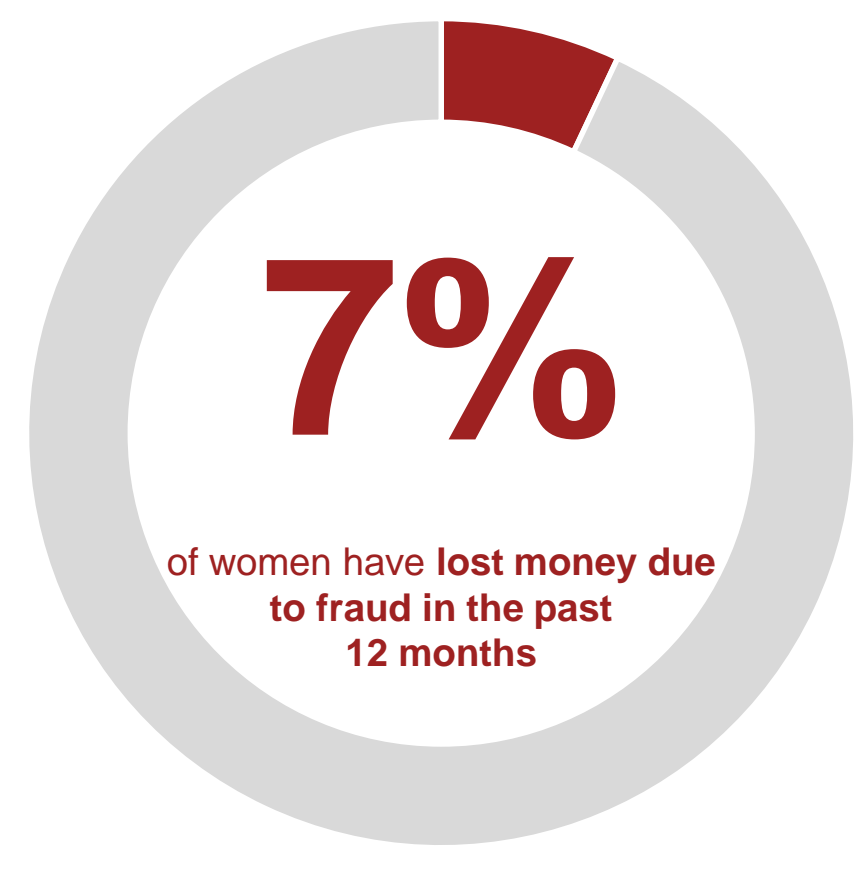

Impact of fraud on overall finances

Among women who lost money in fraud or a scam (n=296)

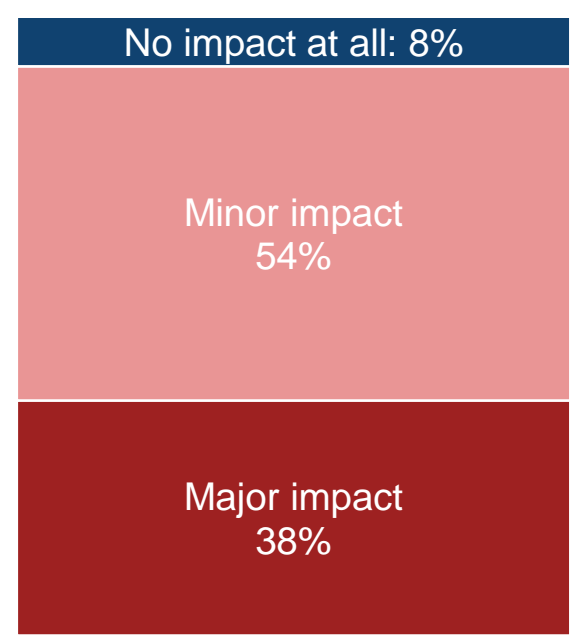




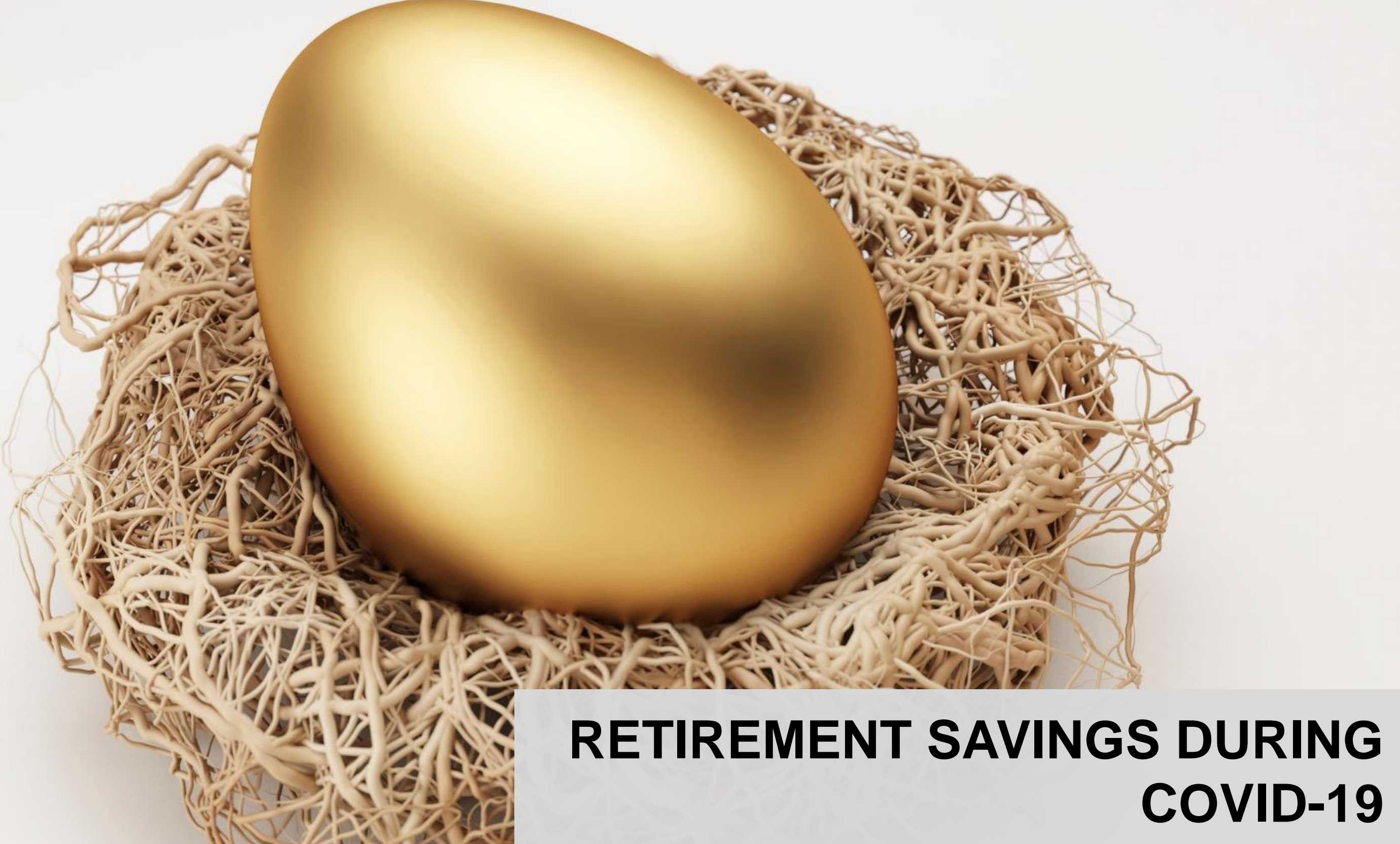

AARP.ORG/RESEARCH | () 2021 AARP ALL RIGHTS RESERVED

IRE $10 \%$ 


\section{Nearly half (47\%) of all women say that they have an employer- provided retirement savings account, including just over half $(55 \%)$ of employed women.}

Employer-provided retirement accounts are more common than retirement accounts outside of work. Just three in 10 $(29 \%)$ women have a retirement account outside of work, including $31 \%$ of employed women. Those who are employed are more likely than those who are not employed to have a retirement savings account. Among those who are not working, fewer than one in four have an employerprovided retirement savings account $(23 \%)$ or a retirement account outside of work (21\%). Women are less likely than men to have a retirement account outside of work.

Q45. Do you own any of the following financial assets or accounts? *Note: Responses related to employer-provided accounts may reflect accounts

offered by a current employer or a former employer. Respondents were not instructed to
Percent who have employer-provided and individual retirement savings accounts

Among all women and by employment status

- Employer-provided retirement savings account (401(k), 403(b), Thrift Savings Plan, or employer-provided IRA)

- Individual retirement savings account outside of an employer (IRA, Keogh, SEP, or other retirement funds)

Total $(n=2,887)$

$28 \%$ $47 \%$
Not employed $(\mathrm{n}=633)$
$21 \%$

$23 \%$
$\%$ with Retirement Account Outside of Work:

$28 \%$ of all women $33 \%{ }^{*}$ of all men

* Indicates a significant difference between segments at a 95\% confidence level 


\section{Among employed women, those} with incomes less than $\$ 40 \mathrm{~K}$ and Hispanic women are especially unlikely to have an employerprovided retirement account.

In fact, only one in four (25\%) employed women with incomes under $\$ 40 \mathrm{~K}$ have an employer-provided retirement savings account, compared to three in four $(76 \%)$ of those with incomes of $\$ 75 \mathrm{~K}$ or more. While $63 \%$ of employed White women say that they have an employer-provided retirement savings account, just $43 \%$ of employed Black women and $31 \%$ of employed Hispanic women do.
Percent who have an employer-provided retirement savings account

Among employed women, by age, income, race/ethnicity, and marital status

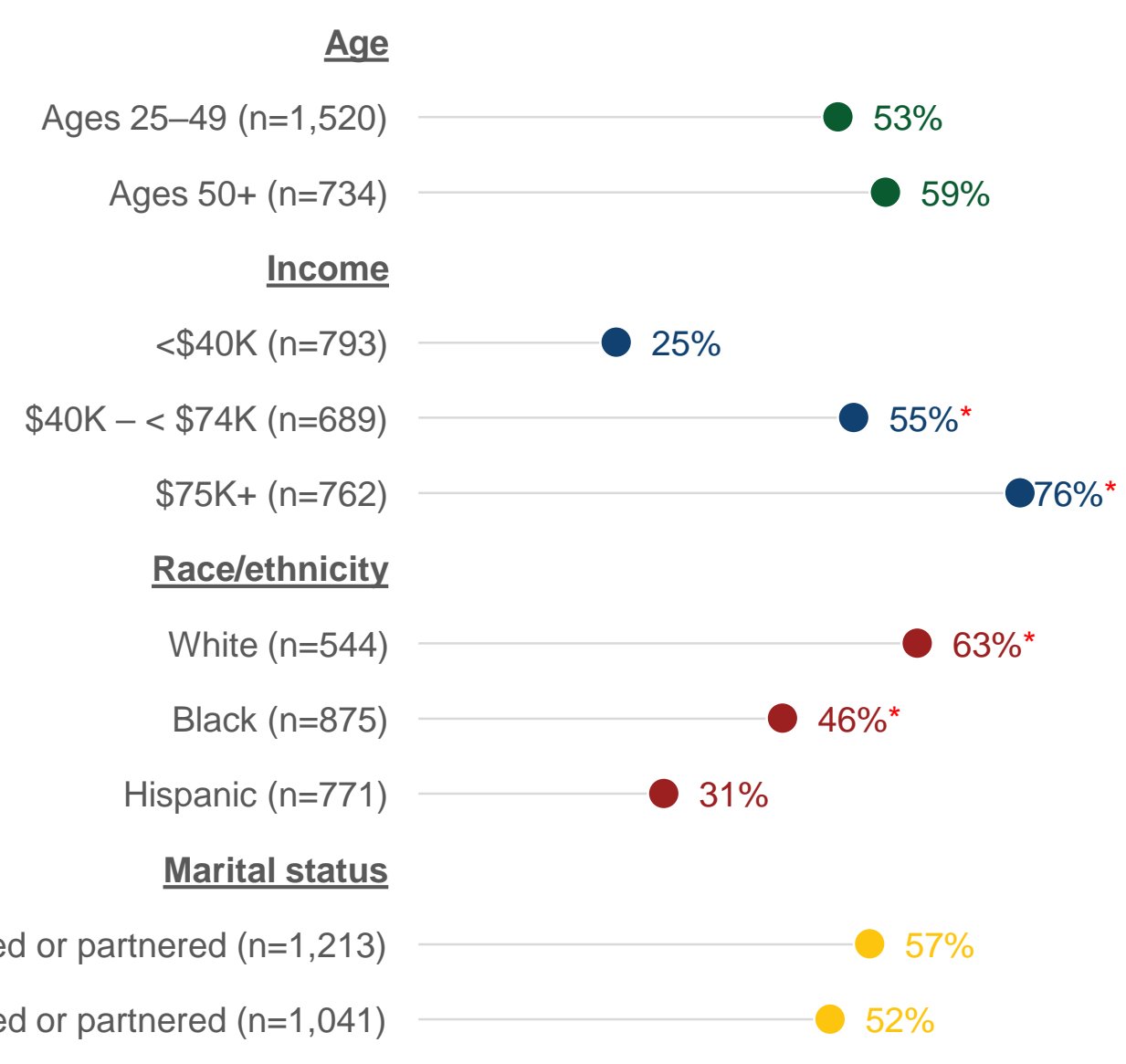




\section{Lack of money and debt are the top barriers to saving more for retirement.}

White women and Black women are more likely than Hispanic women to cite debt payments (White $48 \%$, Black 43\%, Hispanic 37\%). Those ages 25-49, those with incomes lower than $\$ 40 \mathrm{~K}$, Black women, Hispanic women, and women who are not married/not partnered are especially likely to say they "don't know where to start" (e.g., Black women 17\%, Hispanic women 18\%, White women 9\%; ages 25-49 15\%, ages 50+6\%; not married/partnered 15\%, married/partnered 10\%).

Those with incomes lower than $\$ 40 \mathrm{~K}$ are also twice as likely to cite "lack of workplace retirement plans" (13\% of $<\$ 40 \mathrm{~K}$ vs. $6 \%$ of $\$ 75 \mathrm{~K}+$ ). Compared to men, women are more likely to cite "lack of money."
Barriers to saving more for retirement Among women $(n=2,887)$

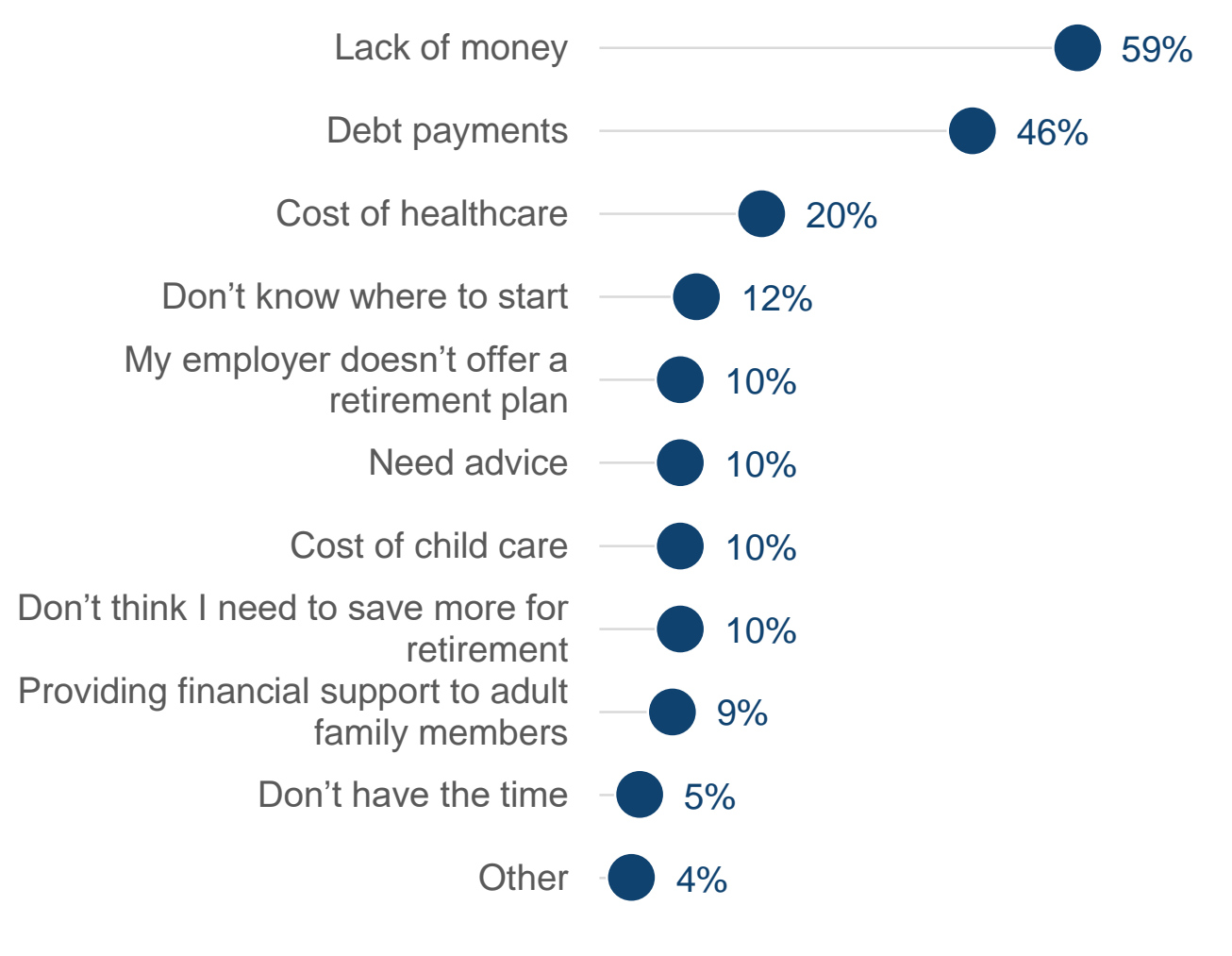

\section{Lack of money: \\ $59 \%$ of women \\ $51 \%$ of men}




\section{Over one in five women prematurely dipped into their retirement savings or stopped contributing altogether during the pandemic.}

Women making less than $\$ 75 \mathrm{~K}$ a year are more likely to have dipped into their retirement savings (25\%) than those making $\$ 75 \mathrm{~K}+(17 \%)$. This was also more common among Hispanic women (27\%) compared to White women (20\%). As might be expected, women who are not working $(30 \%)$ were more likely than those who are currently employed (20\%) to have dipped into their retirement savings.

Actions taken regarding retirement savings since the COVID-19 pandemic began Among women $(n=2,887)$

Taken money from retirement savings earlier than expected (loan or a withdrawal)

Stopped contributing to a $401(\mathrm{k})$ or other retirement savings accounts

Contributed more to a $401(k)$ or other retirement savings accounts than before the pandemic began

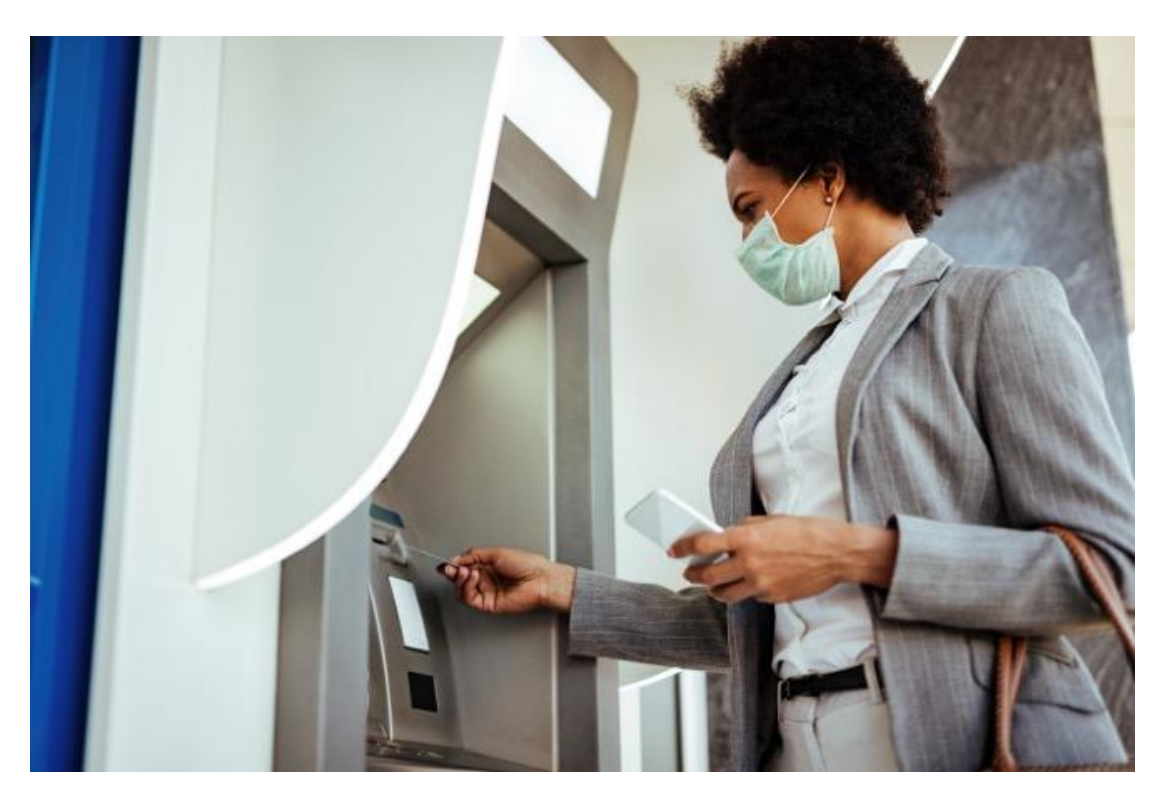

Q35. Since the Coronavirus (COVID 19) pandemic began, have you done any of the following? (Multiple responses allowed.) 


\section{Being financially secure and} not a burden to others are very important retirement goals for most women, though few are confident they will achieve them.

While more than eight in $10(86 \%)$ women say that it is very important to them to be financially secure in retirement, just one in three (33\%) say that they are very likely to achieve this. Similarly, roughly eight in $10(79 \%)$ say that not being a burden to others in retirement is very important to them, but fewer than four in $10(36 \%)$ feel they will be very likely to achieve this.
Importance of and likelihood of achieving the following retirement goals

Very important to achieve and think they are very likely to achieve

Among women $(n=2,887)$

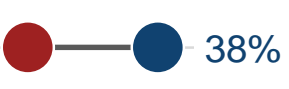




\section{Regardless of demographics, women are much less likely to expect to achieve these retirement goals-financial security and not being a burden- than to say they are important.}

Expectations of achieving these retirement goals are highest among women making $\$ 75 \mathrm{~K}+$ as well as among Black women and Hispanic women.

Being financially secure in retirement

Very important and very likely to achieve among women

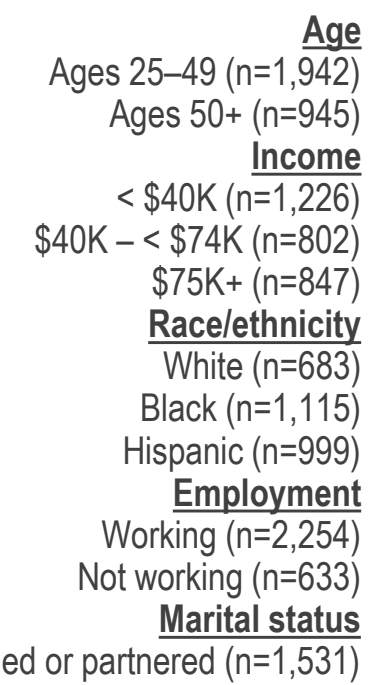

Married or partnered $(n=1,531)$ Not married or partnered $(n=1,356)$
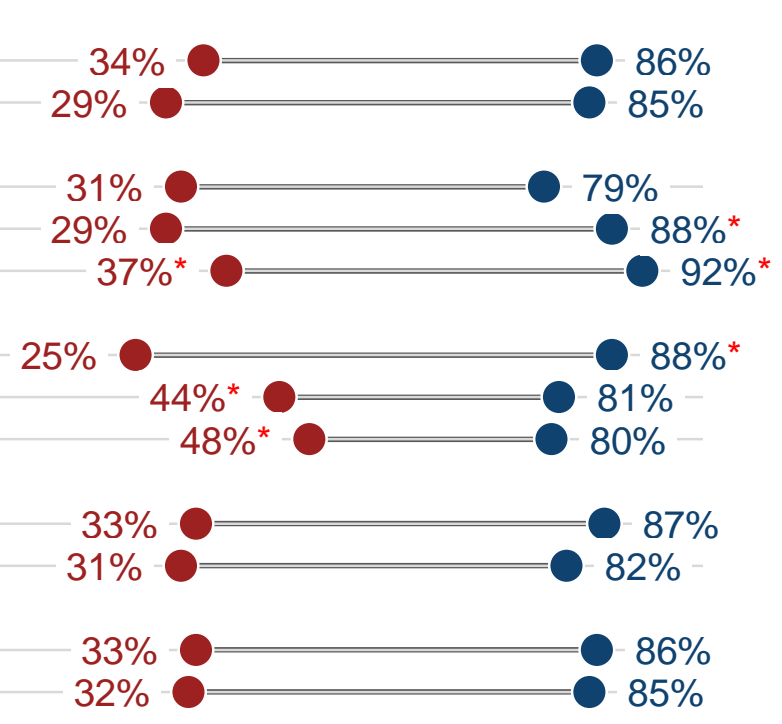

Not being a burden to others in retirement

Very important and very likely to achieve among women

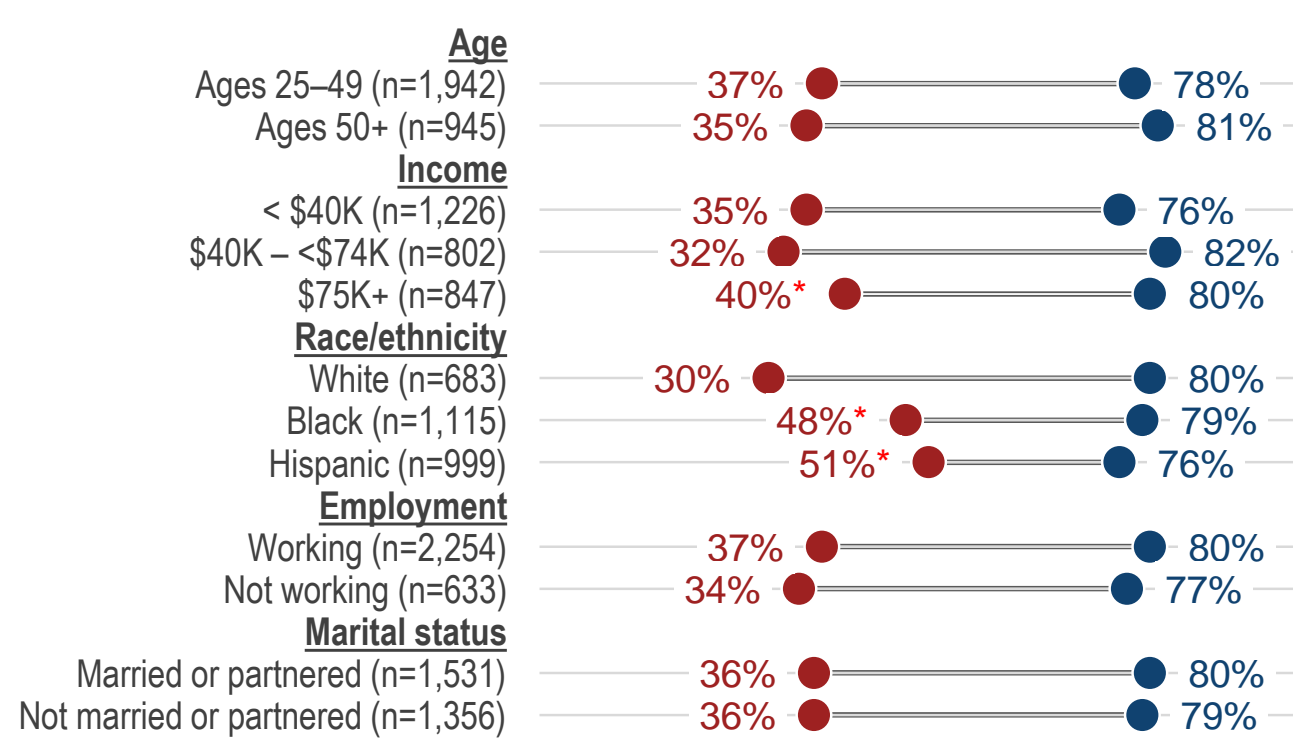




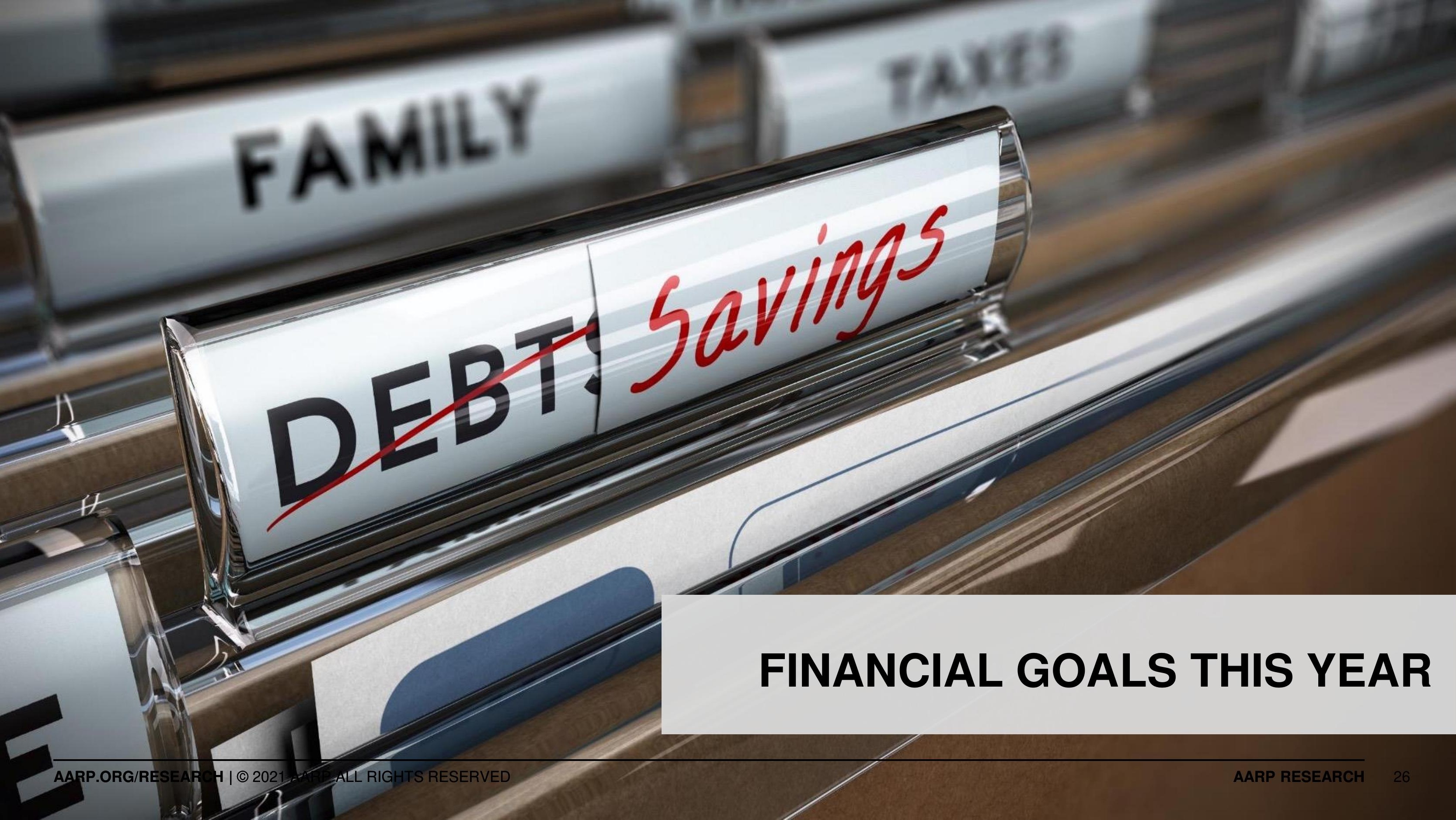




\section{Debt, expenses, and retirement are the top financial issues that women expect to address over the next 12 months.}

Among women who expect to work on debt over the next 12 months, most (63\%) will be working on their credit card balances.

Financial issues expected to tackle

Within the next 12 months

Among women $(n=2,887)$

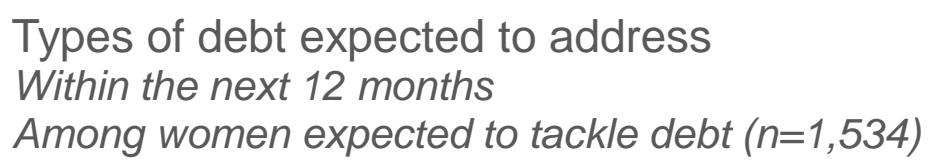

Types of debt expected to address

Within the next 12 months

Among women expected to tackle debt $(n=1,534)$

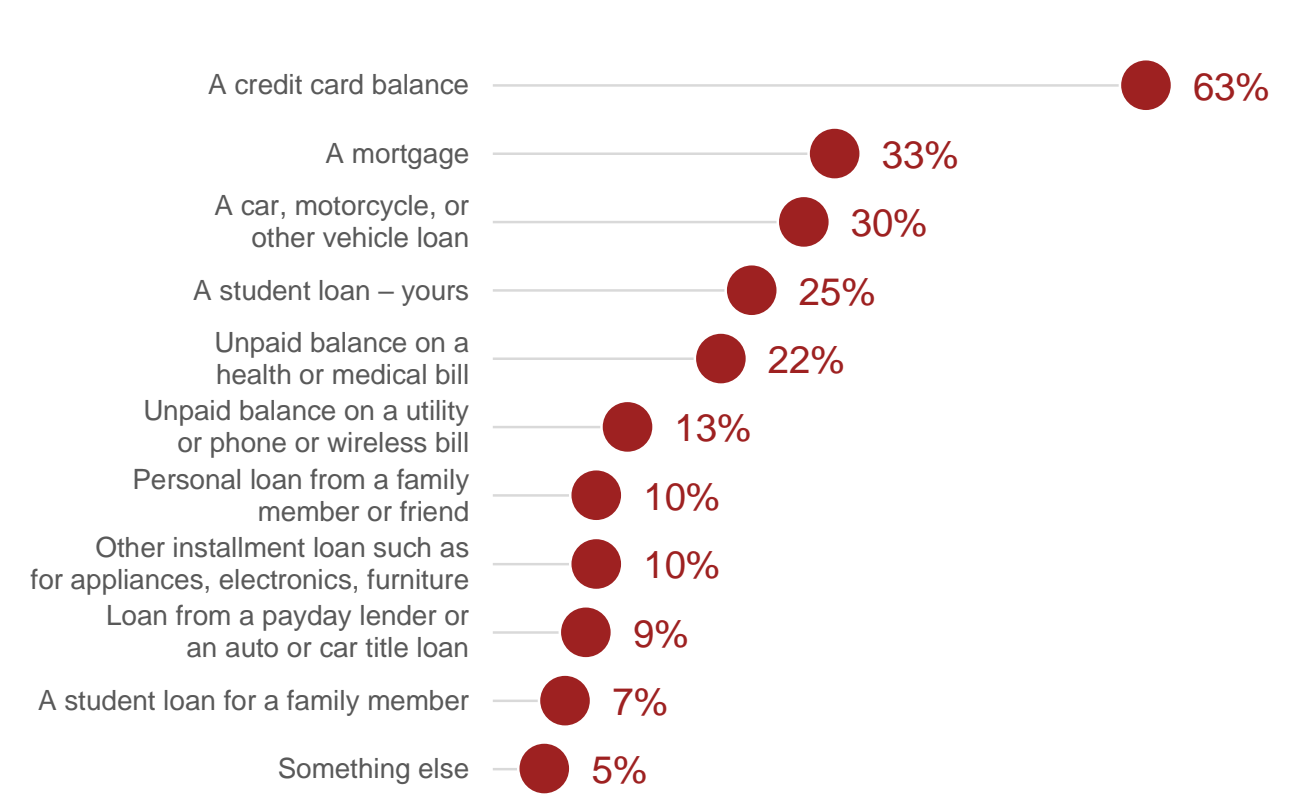




\section{Regardless of demographics, debt is a top issue that women expect to tackle this year.}

'Here and now" issues, such as debt and expenses, represent the most common areas of focus for many. Women making more than $\$ 40 \mathrm{~K}$, White women, and Black women are more likely than their counterparts to expect to address debt. For example, more than half of White women (53\%) and Black women (55\%) expect to work on debt, compared to just $43 \%$ of Hispanic women. More than half $(53 \%)$ of women ages 25-49 expect to work on managing expenses, compared to just $39 \%$ of those ages 50 -plus.

Financial Issues Expected to Tackle

Base: All Women

\begin{tabular}{|c|c|c|c|c|c|c|c|c|c|c|c|c|}
\hline & \multicolumn{2}{|c|}{ Age } & \multicolumn{3}{|c|}{ Household Income } & \multicolumn{3}{|c|}{ Race/ Ethnicity } & \multicolumn{2}{|c|}{$\begin{array}{c}\text { Employment } \\
\text { Status }\end{array}$} & \multicolumn{2}{|c|}{ Marital Status } \\
\hline & 25-49 & $50+$ & $<\$ 40 \mathrm{~K}$ & $\begin{array}{c}\$ 40- \\
<\$ 74 K\end{array}$ & $\$ 75 K_{+}$ & White & Black & Hispanic & Working & $\begin{array}{c}\text { Not } \\
\text { Working }\end{array}$ & $\begin{array}{l}\text { Married/ } \\
\text { partnered }\end{array}$ & $\begin{array}{c}\text { Not } \\
\text { married/ } \\
\text { partnered }\end{array}$ \\
\hline Base: Women & 1,942 & 945 & 1,226 & 802 & 847 & 683 & 1,115 & 999 & 2,254 & 633 & 1,531 & 1,356 \\
\hline Any (NET) & $91 \%{ }^{*}$ & $87 \%$ & $88 \%$ & $90 \%$ & $91 \%$ & $90 \%$ & $89 \%$ & $89 \%$ & $90 \%$ & $89 \%$ & $89 \%$ & $90 \%$ \\
\hline Reducing your debt/managing your debt & $54 \%$ & $50 \%$ & $48 \%$ & $56 \% *$ & $54 \%{ }^{*}$ & $53 \% *$ & $55 \%{ }^{*}$ & $43 \%$ & $53 \%$ & $51 \%$ & $52 \%$ & $54 \%$ \\
\hline Budgeting or managing expenses & $53 \% *$ & $39 \%$ & $47 \%$ & $53 \%{ }^{*}$ & $43 \%$ & $48 \%$ & $49 \%{ }^{*}$ & $43 \%$ & $48 \%$ & $47 \%$ & $46 \%$ & $51 \%$ \\
\hline Retirement savings/planning & $38 \%$ & $47 \%^{*}$ & $30 \%$ & $42 \%{ }^{*}$ & $53 \%{ }^{*}$ & $46 \%{ }^{*}$ & $36 \%$ & $32 \%$ & $44 \%{ }^{*}$ & $34 \%$ & $43 \%$ & $40 \%$ \\
\hline Planning for a large purchase & $24 \%{ }^{*}$ & $13 \%$ & $14 \%$ & $22 \%{ }^{*}$ & $23 \%{ }^{*}$ & $19 \%$ & $22 \%$ & $18 \%$ & $21 \%{ }^{*}$ & $15 \%$ & $21 \%$ & $18 \%$ \\
\hline $\begin{array}{l}\text { Investment planning (not specific to } \\
\text { retirement) }\end{array}$ & $18 \%$ & $13 \%$ & $11 \%$ & $15 \%{ }^{*}$ & $23 \%{ }^{*}$ & $15 \%$ & $21 \%$ * & $14 \%$ & $17 \%$ & $14 \%$ & $16 \%$ & $17 \%$ \\
\hline College savings/planning & $14 \%{ }^{*}$ & $7 \%$ & $9 \%$ & $10 \%$ & $15 \%{ }^{*}$ & $10 \%$ & $9 \%$ & $15 \% *$ & $12 \%$ & $10 \%$ & $14 \% *$ & $7 \%$ \\
\hline $\begin{array}{l}\text { Financial issues related to caring for an } \\
\text { adult relative or loved one }\end{array}$ & $8 \%$ & $7 \%$ & $9 \% *$ & $7 \%$ & $6 \%$ & $7 \%$ & $9 \%$ & $9 \%$ & $7 \%$ & $9 \%$ & $7 \%$ & $8 \%$ \\
\hline $\begin{array}{l}\text { Financial issues related to a change in } \\
\text { marital status }\end{array}$ & $8 \% *$ & $4 \%$ & $8 \%$ & $7 \%$ & $5 \%$ & $7 \%$ & $9 \% *$ & $6 \%$ & $6 \%$ & $8 \%$ & $6 \%$ & $8 \%$ \\
\hline Other & $3 \%$ & $3 \%$ & $4 \%$ & $4 \%$ & $2 \%$ & $4 \%$ & $2 \%$ & $2 \%$ & $3 \%$ & $4 \%$ & $3 \%$ & $4 \%$ \\
\hline Nothing & $9 \%$ & $13 \%{ }^{*}$ & $11 \%$ & $10 \%$ & $9 \%$ & $10 \%$ & $11 \%$ & $11 \%$ & $10 \%$ & $11 \%$ & $10 \%$ & $10 \%$ \\
\hline
\end{tabular}




\section{Among women who expect to work on finances in the next year, 73\% will be seeking help, with nearly as many turning to friends/family as to professionals.}

Women ages 50-plus are more likely to expect to use a financial professional (34\%, vs. $25 \%$ of those ages 25-49), whereas women ages 25-49 are more likely to look for help from a friend or family member $(29 \%$ vs. $18 \%$ of those ages 50 -plus).

Expected sources of financial information in the next 12 months Among women who expect to work on their finances in the next 12 months $(n=2,585)$

Financial professional

Friends and family
Financial websites and apps

Your financial institution Online search engines

Your creditors

Your employer

Other 


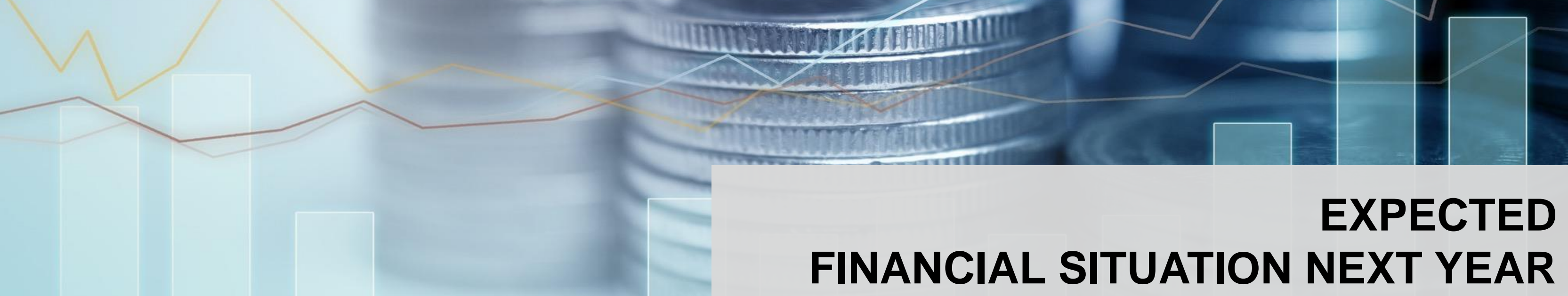




\section{Most women ages 25-plus expect their financial situation to improve or remain the same over the next year.}

A majority of women (55\%) expect their overall financial situation to be better this time next year. Roughly four in 10 expect improvements in their ability to manage their debt, save for emergencies, and save for retirement. Those whose situation had improved over the past year are the most likely to expect their situation to be even better this time next year (68\%), while more than half $(56 \%)$ of those whose situations worsened over the past year expect their situation to improve. Of those whose situations remained the same last year, $46 \%$ expect their situation to improve in the coming year.

Expected change in financial situation a year from now

Among women $(n=2,887)$

-Worse $\Vdash$ Same -Better

Overall $12 \%$ $33 \%$ $55 \%$ 


\section{Black women, Hispanic}

\section{women, younger women,} and those with lower incomes are especially likely to expect their overall

\section{situation to improve.}

Nearly three in four (74\%) Black women expect their situation to be better a year from now as do more than six in 10 $(66 \%)$ Hispanic women, compared to $47 \%$ of White women. Also relatively likely to expect their situations to improve are those with incomes less than $\$ 40 \mathrm{~K}$ (58\% vs. $50 \%$ of those with incomes of $\$ 75 \mathrm{~K}+)$ and women ages $25-49(62 \%$ vs. $43 \%$ of those ages $50+$ ).

Q10. Now looking ahead to this time next year, do you expect your personal financial situation to be better than it is now, worse than it is now, or the same as it is now? Base: Women $(n=2,887)$ * Indicates a
Expected change in overall financial situation next year

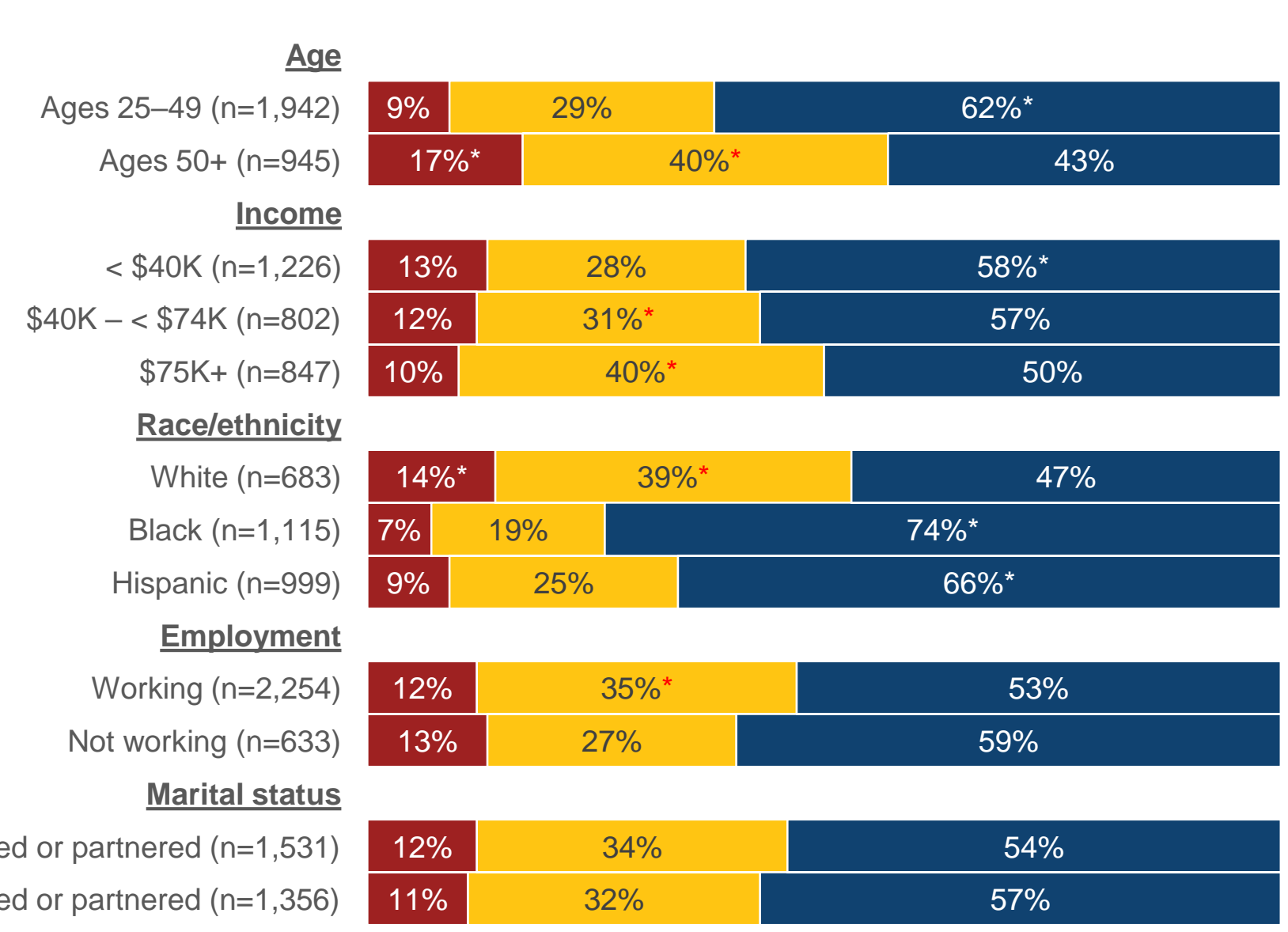

Note: The high optimism among Black women and Hispanic women may reflect not only expectations of more stable employment as the pandemic recedes but also a greater propensity to express optimism in surveys. This may also partly reflect optimism related to the new presidential administration, which began during the fielding of this survey. 


\section{Expectations of increased} income from work, a new job, and lower debt are the top reasons that women believe their financial situation will improve.

Among the $55 \%$ of women who expect their situation to improve in a year, nearly four in 10 cite an expectation of more income from work or a new job as "major" reasons. Roughly a third indicate decreased debt as a major reason. When forced to name one main reason, a full one in four say they expect a new job. Women ages 25-49 are more likely than women ages 50-plus to cite more income from work (41\% vs. 34\%) and a new job (42\% vs. $27 \%$ ) as major reasons.
Reasons for expecting a better financial situation next year Among women who expect a better financial situation next year $(n=1,858)$

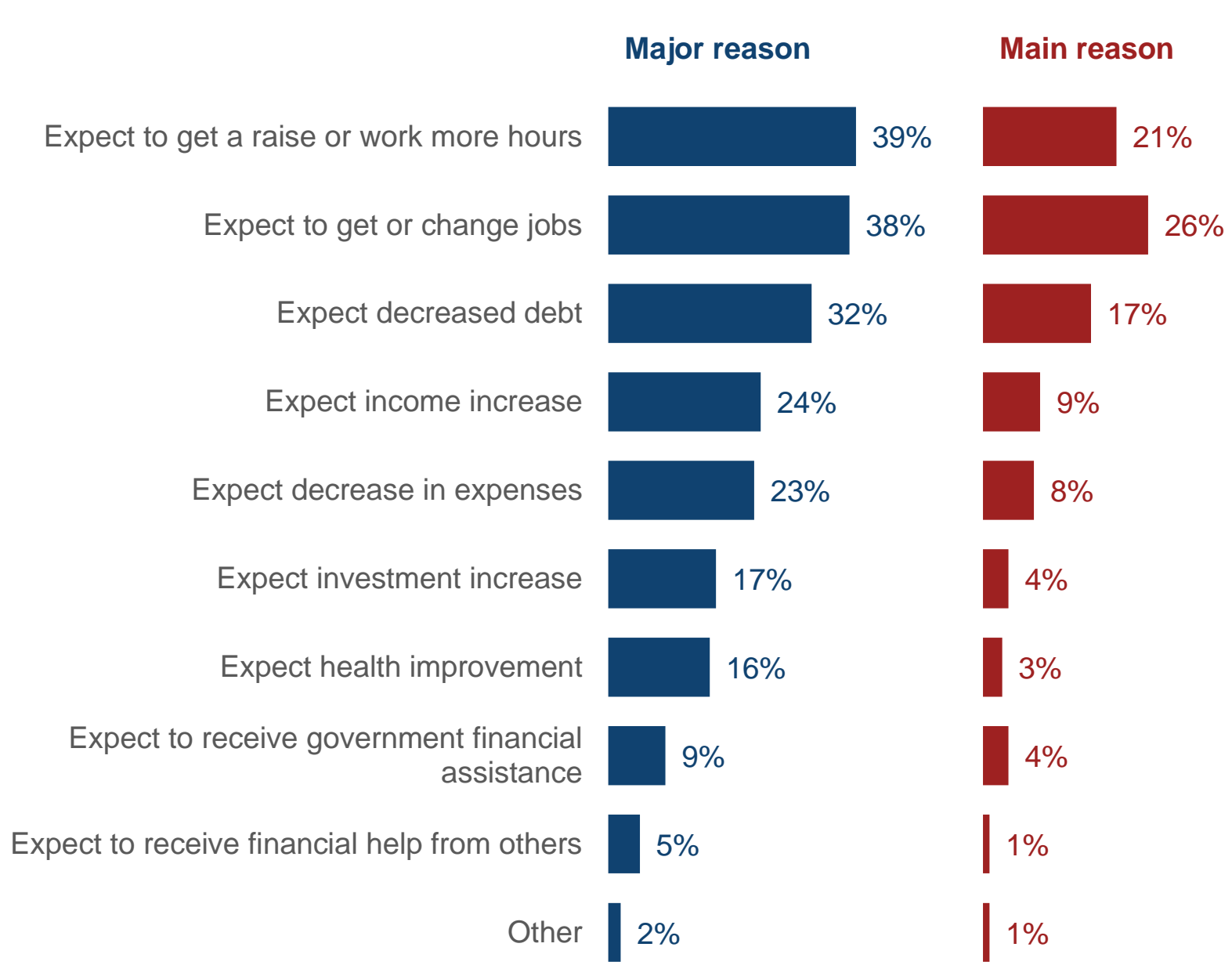




\section{The few who expect to be worse off in a year cite declining income and increasing expenses as the top reasons.}

Of the $12 \%$ of women who expect their finances to be worse next year, about half cite an expectation of declining household income (51\%) or increasing expenses (45\%) as a "major" reason. When forced to name one main reason, about one in five (21\%) say they expect their expenses to increase. Increasing debt emerges more often as a major reason for women ages $25-49(49 \%)$ than for those $50+(23 \%)$, as it does for women with incomes under $\$ 75 \mathrm{~K}(38 \%)$ compared to those making $\$ 75 \mathrm{~K}+(26 \%)$, and for Hispanic women $(47 \%)$ compared to Black women (32\%) and White women (30\%).
Reasons for expecting a worse financial situation next year Among women who expect a worse financial situation next year $(n=244)$

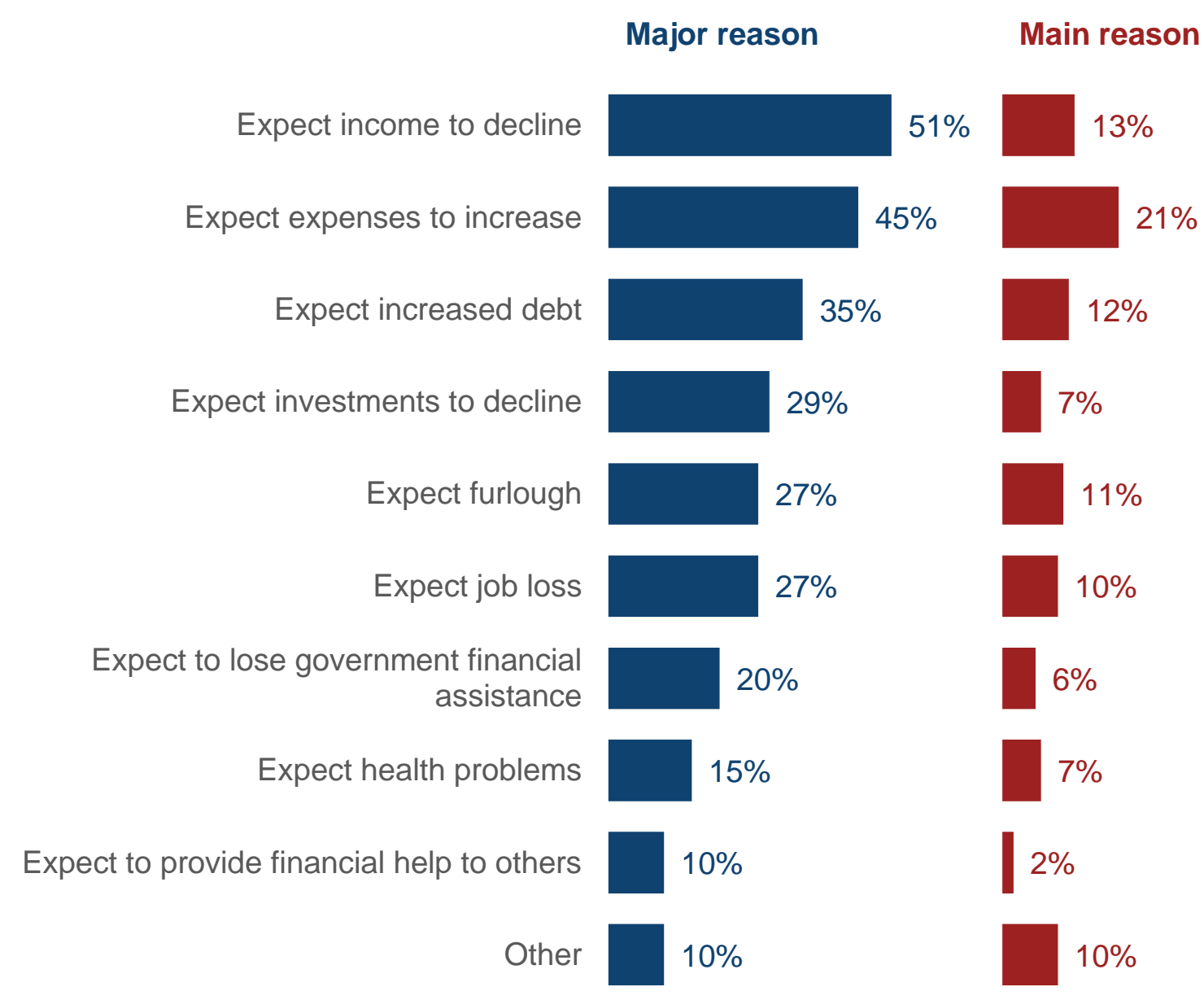




\section{The vast majority of women support the creation of workplace programs to help workers build their emergency savings.}

Roughly nine in 10 women express support for each of the proposals below to help workers save more for emergencies, including roughly half who strongly support each proposal.

Support for workplace programs to help workers save for emergencies Among women $(n=2,887)$

- Strongly oppose

- Somewhat oppose

$\square$ Somewhat support

- Strongly support

Employee benefit that helps employees save a small portion of each paycheck automatically into an emergency fund that each employee owns and controls

Laws that make it easier for employers to offer a safe and simple way for employees to save for emergencies

Tax incentive for workers to save for emergencies

The ability for employers to help employees save from their paychecks into one account that could be used for more than one purpose, such as retirement and emergencies, without needing to pay fees or penalties to withdraw

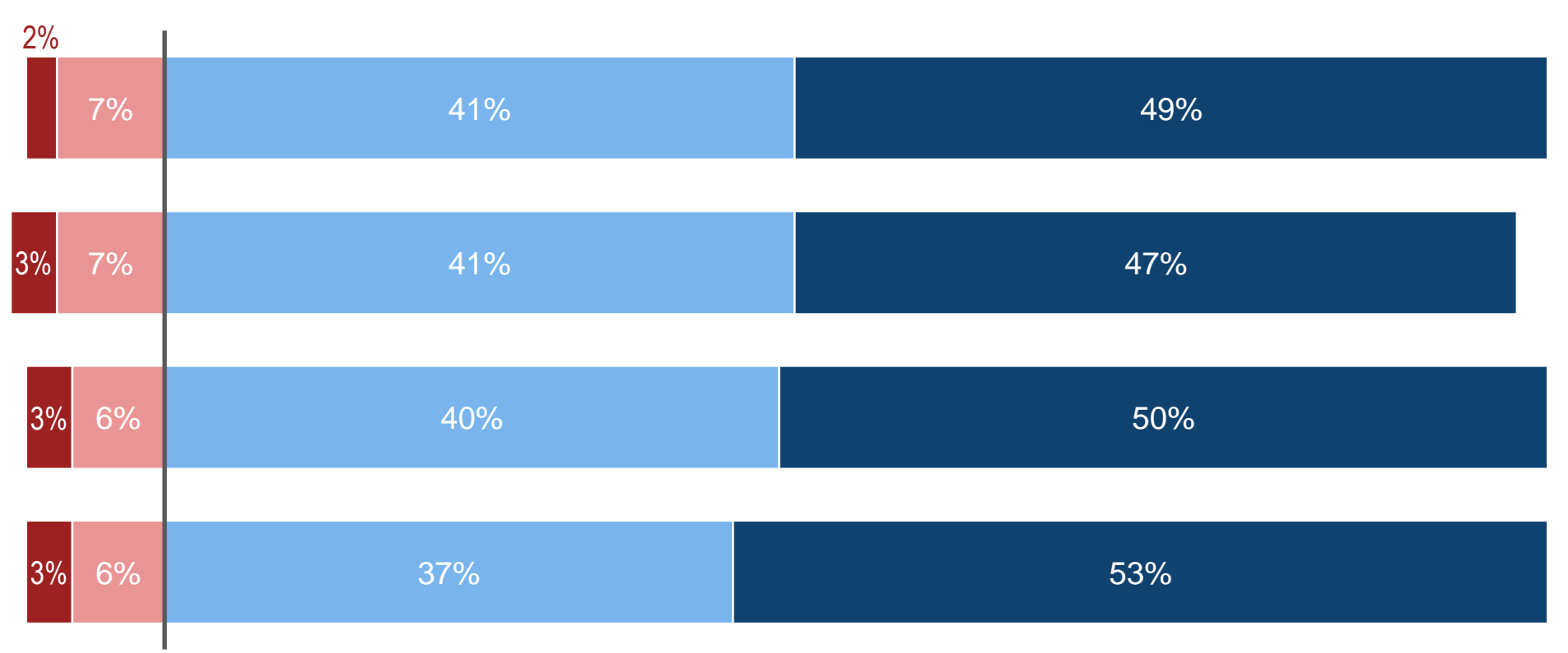




\section{Support for workplace emergency savings programs is widespread across demographic groups.}

Regardless of demographics, roughly nine in 10 women express support for each of various methods for helping workers save for emergencies.

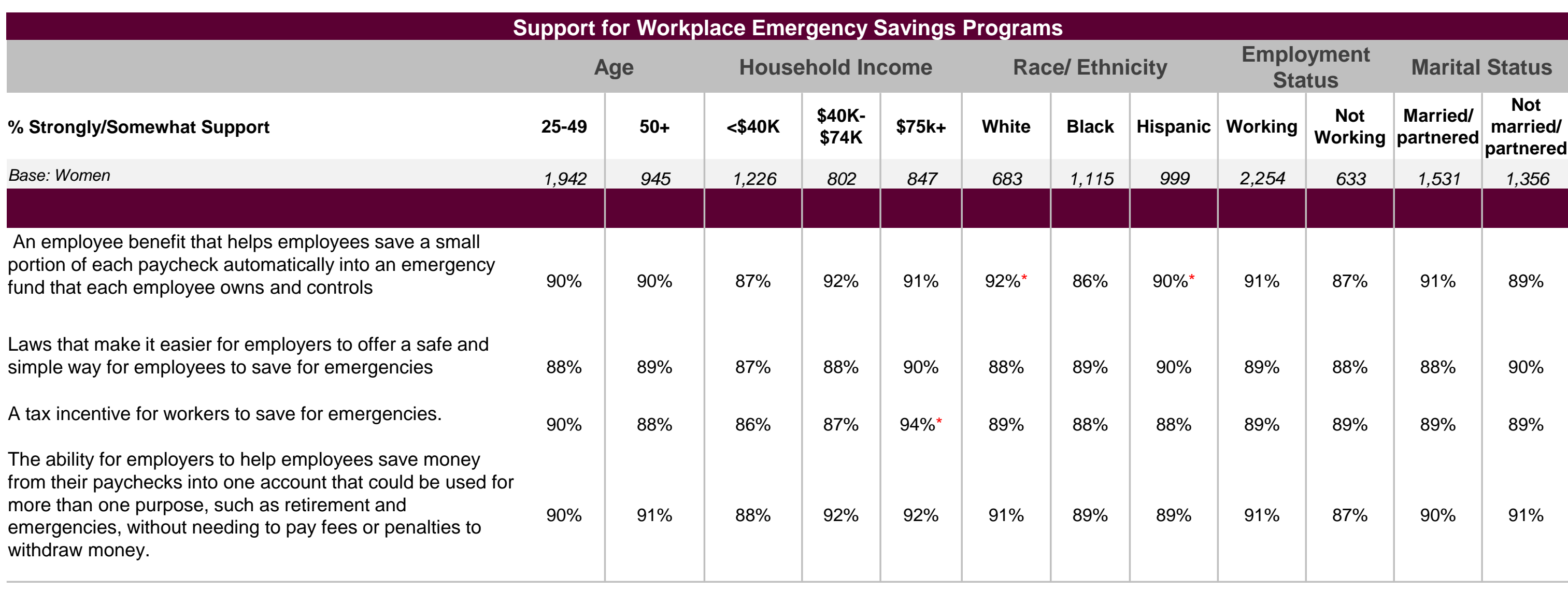

Q42. Some employers look for ways to help workers prepare for future emergencies. How much do you support or oppose each of the following proposals? 



\section{Implications}

Job changes as well as changes in income, debt, and expenses appear to be the primary determinants of how working women fared financially during the pandemic.

- Among women who are worse off today, most have experienced declines in their ability to save (for emergencies and for retirement) as well as in their ability to manage their debt. Their finances may take quite some time to recover. Because women are more likely than men to be worse off today than before the pandemic, women may be especially likely to benefit from financial assistance programs and resources to help with job reskilling, job searches, debt management, budgeting, and savings.

- Although the majority of women are optimistic that their situation will improve over the coming year, this optimism hinges on expectations of more stable employment and reduced debt.

Debt's key role in shaping financial circumstances is clear from the fact that it is the top financial issue that women expect to tackle this year. Even though many feel they are "managing" their debt, this may simply mean that they can cover their debt payments even if they have nothing left over to save. Recurring debt payments have the potential to severely hamper the ability to save for emergencies and for retirement.

Savings, both savings for emergencies and for retirement, are critical components of financial security with which many women struggle. Women express widespread support for establishing workplace emergency savings programs. Such programs represent a useful supplement to workplace retirement savings programs, which play a key role in helping workers build retirement savings. The relatively low share of lower-income, Black, and Hispanic women who have workplace retirement accounts is a testament to the fact that established workplace retirement programs are not reaching all segments of the workforce equally -especially vulnerable populations that are not only less likely to have access to such programs but also often have higher expenses relative to income, which makes saving for the future more difficult. 


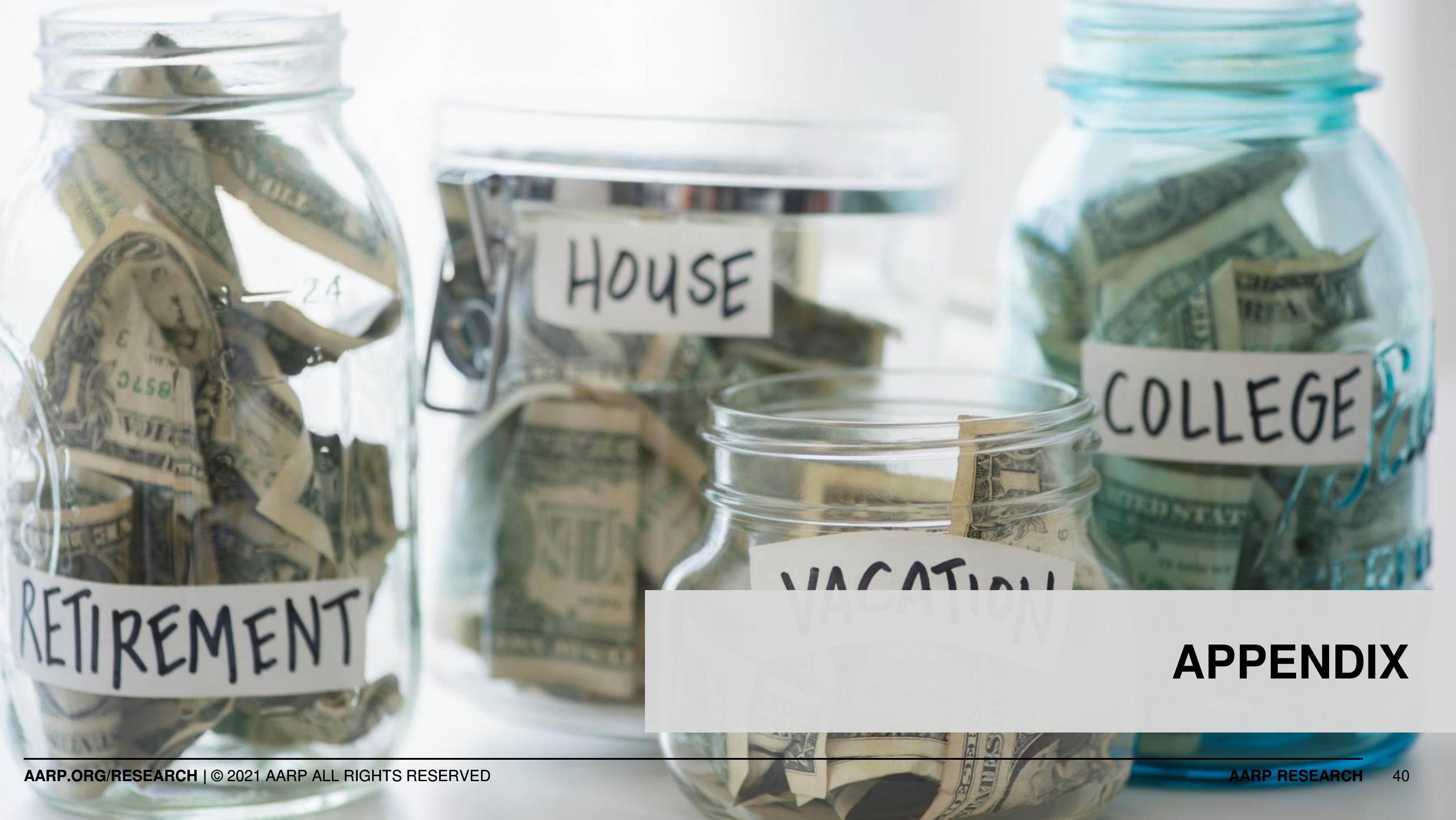




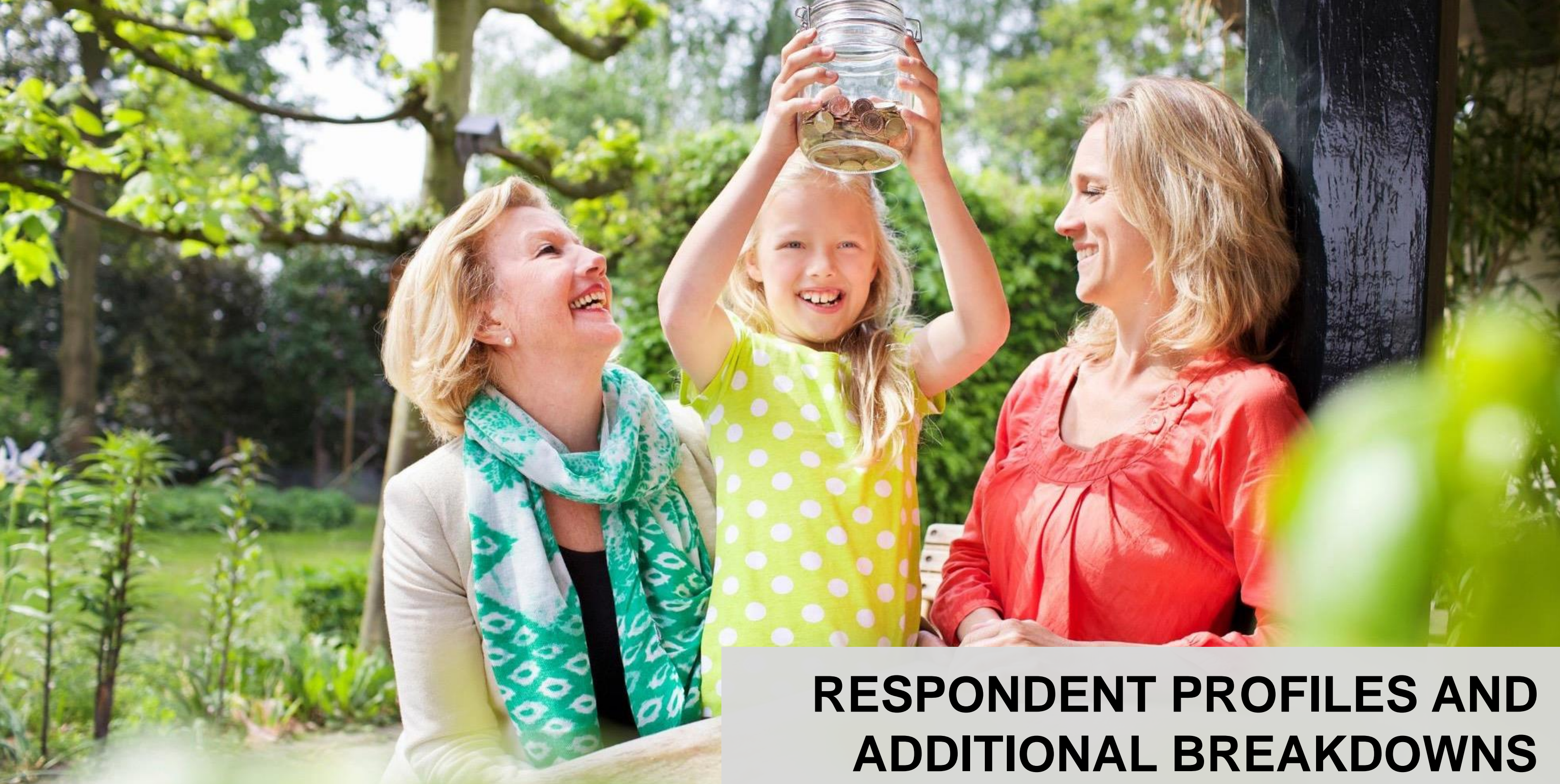




\section{Women's satisfaction with ability to manage debt, save for emergencies, and save for retirement - by demographics}

\begin{tabular}{|c|c|c|c|c|c|c|c|c|c|c|c|c|}
\hline & \multicolumn{2}{|c|}{ Age } & \multicolumn{3}{|c|}{ Household Income } & \multicolumn{3}{|c|}{ Race/ Ethnicity } & \multicolumn{2}{|c|}{ Employment Status } & \multicolumn{2}{|c|}{ Marital Status } \\
\hline & $25-49$ & $50+$ & $<\$ 40 \mathrm{~K}$ & $\begin{array}{l}\$ 40 \mathrm{~K}- \\
<\$ 74 \mathrm{~K}\end{array}$ & $\$ 75 K+$ & White & Black & Hispanic & Working & $\begin{array}{c}\text { Not } \\
\text { Working }\end{array}$ & $\begin{array}{l}\text { Married/ } \\
\text { partnered }\end{array}$ & $\begin{array}{c}\text { Not } \\
\text { married/ } \\
\text { partnered }\end{array}$ \\
\hline Base: Women & 1,942 & 945 & 1,226 & 802 & 847 & 683 & 1,115 & 999 & 2,254 & 633 & 1,531 & 1,356 \\
\hline \multicolumn{13}{|l|}{$\%$ Very/Somewhat Satisfied } \\
\hline Your ability to manage your debt & $64 \%$ & $79 \%{ }^{*}$ & $60 \%$ & $68 \% *$ & $80 \% *$ & $72 \% *$ & $64 \%$ & $70 \%{ }^{*}$ & $72 \%{ }^{*}$ & $61 \%$ & $72 \%{ }^{*}$ & $66 \%$ \\
\hline \multicolumn{13}{|l|}{ Your ability to save for emergencies } \\
\hline Your ability to save for retirement & $43 \%$ & $44 \%$ & $26 \%$ & $38 \% *$ & $66 \% *$ & $45 \%$ & $43 \%$ & $43 \%$ & $47 \% *$ & $32 \%$ & $49 \% *$ & $36 \%$ \\
\hline
\end{tabular}




\section{Types of debt held by women - by demographics}

\begin{tabular}{|c|c|c|c|c|c|c|c|c|}
\hline & \multicolumn{2}{|c|}{ Age } & \multicolumn{3}{|c|}{ Income } & \multicolumn{3}{|c|}{ Race/Ethnicity } \\
\hline & $25-49$ & $50+$ & $<\$ 40 k$ & $\$ 40 k-<\$ 74 k$ & $\$ 75 k+$ & White & Black & Hispanic \\
\hline Base: Women & 1,942 & 945 & 1,226 & 802 & 847 & 683 & 1,115 & 999 \\
\hline Any (NET) & $90 \% *$ & $86 \%$ & $85 \%$ & $92 \% *$ & $89 \%$ & $90 \% *$ & $87 \%$ & $84 \%$ \\
\hline A credit card balance & $48 \%$ & $53 \% *$ & $51 \%$ & $54 \% *$ & $45 \%$ & $50 \%$ & $47 \%$ & $50 \%$ \\
\hline A mortgage & $38 \%$ & $44 \% *$ & $17 \%$ & $46 \%{ }^{*}$ & $60 \% *$ & $48 \% *$ & $24 \%$ & $23 \%$ \\
\hline A car, motorcycle, or other vehicle loan & $40 \%$ & $39 \%$ & $26 \%$ & $47 \% *$ & $48 \%{ }^{*}$ & $45 \% *$ & $30 \%$ & $27 \%$ \\
\hline Unpaid balance on a health/medical bill & $24 \% *$ & $17 \%$ & $25 \%{ }^{*}$ & $25 \% *$ & $15 \%$ & $23 \% *$ & $23 \% *$ & $16 \%$ \\
\hline A student loan - yours & $28 \% *$ & $10 \%$ & $18 \%$ & $24 \%$ & $23 \%$ & $20 \% *$ & $31 \% *$ & $13 \%$ \\
\hline Unpaid balance on a utility or phone/wireless bill & $18 \% *$ & $8 \%$ & $23 \%{ }^{*}$ & $13 \% *$ & $6 \%$ & $11 \%$ & $21 \% *$ & $19 \%{ }^{*}$ \\
\hline Personal loan from a family member or friend & $12 \% *$ & $6 \%$ & $11 \%{ }^{*}$ & $10 \%$ & $7 \%$ & $8 \%$ & $9 \%$ & $14 \%{ }^{*}$ \\
\hline Loan from a payday lender or an auto/car title loan & $8 \% *$ & $5 \%$ & $10 \% *$ & $6 \%$ & $6 \%$ & $5 \%$ & $12 \% *$ & $9 \% *$ \\
\hline A student loan for a family member & $8 \%$ & $6 \%$ & $6 \%$ & $7 \%$ & $9 \%$ & $6 \%$ & $8 \%$ & $8 \%$ \\
\hline Other installment loan & $10 \%$ & $11 \%$ & $8 \%$ & $14 \%$ & $10 \%$ & $12 \%{ }^{*}$ & $9 \%$ & $8 \%$ \\
\hline Something else & $3 \%$ & $5 \%{ }^{*}$ & $3 \%$ & $3 \%$ & $4 \%$ & $4 \% *$ & $1 \%$ & $2 \%$ \\
\hline None - I have/carry no debt month-to-month & $10 \%$ & $13 \% *$ & $15 \%{ }^{*}$ & $8 \%$ & $10 \%$ & $10 \%$ & $13 \%$ & $16 \%{ }^{*}$ \\
\hline
\end{tabular}




\section{Demographic profile}

\begin{tabular}{|c|c|c|c|}
\hline & \multirow[t]{2}{*}{ Total } & \multicolumn{2}{|c|}{$\begin{array}{l}\text { Satisfaction with Overall } \\
\text { Financial Situation }\end{array}$} \\
\hline & & Satisfied & Not Satisfied \\
\hline Base: Women & 2,887 & 1,557 & 1,326 \\
\hline \multicolumn{4}{|l|}{ AGE } \\
\hline $25-34$ & $27 \%$ & $24 \%$ & $30 \% *$ \\
\hline $35-49$ & $36 \%$ & $35 \%$ & $38 \%$ \\
\hline $50-59$ & $23 \%$ & $25 \% *$ & $20 \%$ \\
\hline $60+$ & $15 \%$ & $17 \% *$ & $12 \%$ \\
\hline \multicolumn{4}{|l|}{ RACE/ETHNICITY } \\
\hline White, non-Hispanic & $61 \%$ & $66 \% *$ & $54 \%$ \\
\hline Black, non-Hispanic & $13 \%$ & $10 \%$ & $16 \%$ * \\
\hline Other, non-Hispanic & $1 \%$ & $1 \%$ & $2 \%$ \\
\hline Hispanic & $18 \%$ & $17 \%$ & $19 \%$ \\
\hline 2+, non-Hispanic & $4 \%$ & $3 \%$ & $6 \% *$ \\
\hline Asian, non-Hispanic & $3 \%$ & $3 \%$ & $3 \%$ \\
\hline \multicolumn{4}{|l|}{ INCOME } \\
\hline$<\$ 30 k$ & $27 \%$ & $18 \%$ & $39 \% *$ \\
\hline$\$ 30 \mathrm{k}-<\$ 60 \mathrm{k}$ & $27 \%$ & $22 \%$ & $34 \% *$ \\
\hline$\$ 60 k-<\$ 100 k$ & $25 \%$ & $29 \% *$ & $20 \%$ \\
\hline$\$ 100 k+$ & $21 \%$ & $32 \% *$ & $7 \%$ \\
\hline
\end{tabular}

AARP.ORG/RESEARCH | @ 2021 AARP ALL RIGHTS RESERVED

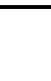

\begin{tabular}{|c|c|c|c|}
\hline & \multirow[t]{2}{*}{ Total } & \multicolumn{2}{|c|}{$\begin{array}{l}\text { Satisfaction with Overall } \\
\text { Financial Situation }\end{array}$} \\
\hline & & Satisfied & Not Satisfied \\
\hline Base: Women & 2,887 & 1,557 & 1,326 \\
\hline \multicolumn{4}{|l|}{ EDUCATION } \\
\hline Less than HS & $8 \%$ & $6 \%$ & $9 \%{ }^{*}$ \\
\hline HS graduate & $26 \%$ & $21 \%$ & $32 \%{ }^{*}$ \\
\hline Vocational/tech school/some college/ associates & $26 \%$ & $25 \%$ & $27 \%$ \\
\hline Bachelor's degree & $23 \%$ & $27 \%{ }^{*}$ & $18 \%$ \\
\hline Post grad study/professional degree & $18 \%$ & $20 \%{ }^{*}$ & $13 \%$ \\
\hline
\end{tabular}

Employed Full-Tim

Employed Part-Time

Unemployed and Looking for Work or on Temporary

Layoff

\begin{tabular}{ccc}
$55 \%$ & $61 \%^{*}$ & $46 \%$ \\
$21 \%$ & $22 \%$ & $20 \%$ \\
$15 \%$ & $9 \%$ & $23 \%^{*}$ \\
$9 \%$ & $7 \%$ & $11 \%^{*}$ \\
\hline & &
\end{tabular}

Not Working - Retired, Disabled, or Other

MARITAL STATUS

$\begin{array}{lccc}\text { Married } & 50 \% & 58 \%^{*} & 39 \% \\ \text { Widowed } & 3 \% & 2 \% & 4 \% \\ \text { Divorced } & 12 \% & 11 \% & 14 \%^{*} \\ \text { Separated } & 4 \% & 4 \% & 5 \% \\ \text { Never married } & 21 \% & 18 \% & 24 \%^{*} \\ \text { Living with partner } & 10 \% & 7 \% & 14 \%^{*} \\ \text { COVID STATUS/HISTORY } & & & \\ \text { Yes, a member of my household has } & 10 \% & 9 \% & 11 \% \\ \text { Yes, I have } & 9 \% & 9 \% & 9 \% \\ \text { No } & 83 \% & 84 \% & 83 \%\end{array}$

* Indicates a percentage that is significantly greater than the corresponding percentage within another segment at a 95\% confidence level 


\section{Financial profile}

\begin{tabular}{|c|c|c|c|c|c|c|c|}
\hline \multirow[b]{3}{*}{ Base: Women } & \multirow{3}{*}{$\begin{array}{c}\text { Women } \\
2,887\end{array}$} & \multicolumn{2}{|c|}{$\begin{array}{l}\text { Satisfaction with Overall } \\
\text { Financial Situation }\end{array}$} & & \multirow[b]{3}{*}{ Women } & \multirow{2}{*}{\multicolumn{2}{|c|}{$\begin{array}{l}\text { Satisfaction with Overall } \\
\text { Financial Situation }\end{array}$}} \\
\hline & & \multirow{2}{*}{$\begin{array}{c}\text { Satisfied } \\
1,557\end{array}$} & \multirow{2}{*}{$\begin{array}{c}\text { Not Satisfied } \\
1,326\end{array}$} & & & & \\
\hline & & & & & & Satisfied & Not Satisfied \\
\hline A credit card balance & $50 \%$ & $42 \%$ & $61 \% *$ & AMOUNT IN RETIREMENT SAVINGS & & & \\
\hline A mortgage & $41 \%$ & $49 \% *$ & $28 \%$ & Base: Owns a retirement savings account & 1,421 & 916 & 504 \\
\hline A car, motorcycle, or other vehicle loan & $40 \%$ & $38 \%$ & $42 \%$ & Less than $\$ 50,000$ (NET) & $43 \%$ & $32 \%$ & $68 \%{ }^{*}$ \\
\hline A student loan - yours & $21 \%$ & $16 \%$ & $28 \%{ }^{*}$ & $\$ 50,000$ to $\$ 300,000$ (NET) & $32 \%$ & $36 \% *$ & $22 \%$ \\
\hline Unpaid balance on a utility or phone/wireless bill & $14 \%$ & $7 \%$ & $25 \%{ }^{*}$ & Not sure & $12 \%$ & $13 \%{ }^{*}$ & $9 \%$ \\
\hline Personal loan from a family member or friend & $9 \%$ & $7 \%$ & $13 \% *$ & VALUE OF NON-RETIREMENT ASSETS & & & \\
\hline A student loan for a family member & $7 \%$ & $8 \%$ & $7 \%$ & Base: Owns financial accounts/financial & 2,440 & 1,364 & 1.072 \\
\hline Loan from a payday lender or an auto/car title loan & $7 \%$ & $5 \%$ & $10 \%{ }^{*}$ & assets outside of a retirement account & 2,440 & 1,364 & $1,0 / 2$ \\
\hline Other installment loan such as for appliances, & & $8 \%$ & $14 \% *$ & Less than $\$ 5,000$ & $39 \%$ & $24 \%$ & $61 \% *$ \\
\hline electronics, furniture & $10 \%$ & $8 \%$ & $14 \%$ & $\$ 5,000$ to less than $\$ 10,000$ & $15 \%$ & $15 \%$ & $14 \%$ \\
\hline Something else & $4 \%$ & $4 \%$ & $3 \%$ & $\$ 10,000$ to less than $\$ 50,000$ & $18 \%$ & $23 \%{ }^{*}$ & $11 \%$ \\
\hline None & $11 \%$ & $13 \%{ }^{*}$ & $8 \%$ & $\$ 50,000$ or more & $17 \%$ & $25 \%{ }^{*}$ & $6 \%$ \\
\hline Checking accounts & $82 \%$ & $85 \%{ }^{*}$ & $77 \%$ & & & & \\
\hline Savings accounts, CDs, or money market accounts & $52 \%$ & $62 \% *$ & $38 \%$ & & & & \\
\hline Employer-provided retirement savings account & $47 \%$ & $57 \% *$ & $34 \%$ & & & & \\
\hline Savings in cash & $37 \%$ & $46 \%{ }^{*}$ & $25 \%$ & & & & \\
\hline Individual retirement account outside of an employer & $29 \%$ & $38 \%{ }^{*}$ & $15 \%$ & & & & \\
\hline Bitcoins or other cryptocurrency & $4 \%$ & $4 \%$ & $4 \%$ & & & & \\
\hline Other personal savings or investments & $22 \%$ & $29 \% *$ & $11 \%$ & & & & \\
\hline $\begin{array}{l}\text { Other financial assets or accounts excluding real } \\
\text { estate or housing }\end{array}$ & $2 \%$ & $3 \%$ & $1 \%$ & & & & \\
\hline None of the above & $10 \%$ & $6 \%$ & $16 \%{ }^{*}$ & $\begin{array}{l}\text { * Indicates a percentage that is significantly } \mathrm{s} \\
\text { another segment at a } 95 \% \text { confidence level }\end{array}$ & than the & ding $p e$ & within \\
\hline
\end{tabular}




\section{Methodology}

This survey was conducted by NORC at the University of Chicago on behalf of AARP. Adults ages $25+$ who indicated they have been employed or have been looking for work in the past 12 months were eligible to complete the survey.

For the general sample, data were collected using NORC's AmeriSpeak® Panel, a probability-based panel designed to be representative of the U.S. household population. In addition, respondents from the Lucid nonprobability online opt-in panel were invited as an oversample supplement to reach 1,911 completes overall for African American/Black respondents and 1,991 completes overall for respondents of Hispanic origin.

Interviews for this survey were conducted in English and Spanish from January 13, 2021 through February 8, 2021. A total of 5,430 respondents completed this survey, including a total of 2,887 women. ${ }^{1}$ As noted previously, this report only contains the responses from women.

The final sample was weighted by age, gender, education, race/ethnicity, and Census Division using February 2020 Current Population Survey benchmarks for adults who are working or looking for work. The weighted data reflect the U.S. population of adults age 25+ who are currently working, looking for work, or had worked or looked for work in the 12 months prior to the survey. In order to incorporate the Lucid nonprobability sample, NORC used TrueNorth calibration services, a hybrid calibration approach developed at NORC based on small area estimation methods in order to explicitly account for potential bias associated with the nonprobability sample.

The margin of error for the overall survey sample is \pm 2.25 percent at the 95 percent confidence level. The margin of error for the sample of women \pm 3.14 percent 


\section{Sources}

${ }^{1}$ Elizabeth Weber Handwerker, Peter B. Meyer, Joseph Piacentini, Michael Schultz, and Leo Sveikauskas, "Employment recovery in the wake of the COVID-19 pandemic," Monthly Labor Review, U.S. Bureau of Labor Statistics, December 2020, https://doi.org/10.21916/mlr.2020.27.

2 J. Schramm, "COVID-19 Takes Toll on Women's Labor Force Participation, Reversing Trend," AARP Public Policy Institute, November 2020,

https://blog.aarp.org/thinking-policy/covid-19-toll-on-womens-labor-force-participation.

3 O Davis, B. Fisher, T. Ghilarducci, and S. Radpour (2020). "A First in Nearly 50 Years, Older Workers Face Higher Unemployment than Mid-Career Workers," Older Workers Report, Schwartz Center for Economic Policy Analysis at The New School for Social Research, October 2020

https://www.economicpolicyresearch.org/jobs-report/a-first-in-nearly-50-years-older-workers-facehigher-unemployment-than-mid-career-workers.

4 Schramm, J. "March 2021 Employment Data Digest," AARP Public Policy Institute, March 2021, https://www.aarp.org/ppi/info-2020/employment-data-digest.html. 


\section{About AARP}

AARP is the nation's largest nonprofit, nonpartisan organization dedicated to empowering Americans 50 and older to choose how they live as they age. With nearly 38 million members and offices in every state, the District of Columbia, Puerto Rico, and the U.S. Virgin Islands, AARP works to strengthen communities and advocate for what matters most to families with a focus on health security, financial stability and personal fulfillment. AARP also works for individuals in the marketplace by sparking new solutions and allowing carefully chosen, high-quality products and services to carry the AARP name. As a trusted source for news and information, AARP produces the nation's largest circulation publications, AARP The Magazine and AARP Bulletin. To learn more, visit www.aarp.org or follow @AARP and @AARPadvocates on social media. 


\section{AARP}

S. Kathi Brown, AARP Research

skbrown@aarp.org

For media inquiries, please contact

media@aarp.org

This research was designed and executed by AARP Research 